\title{
Globalization, first-foods systems transformations and corporate power: a synthesis of literature and data on the market and political practices of the transnational baby food industry
}

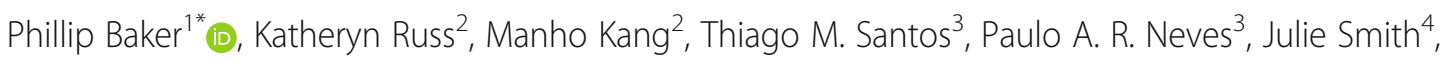 \\ Gillian Kingston ${ }^{5}$, Melissa Mialon ${ }^{6}$, Mark Lawrence ${ }^{1}$, Benjamin Wood ${ }^{7}$, Rob Moodie $^{8}$, David Clark' \\ Katherine Sievert ${ }^{10}$, Monique Boatwright ${ }^{10}$ and David McCoy ${ }^{10}$
}

\begin{abstract}
Background: The global milk formula market has 'boomed' in recent decades, raising serious concerns for breastfeeding, and child and maternal health. Despite these developments, few studies have investigated the global expansion of the baby food industry, nor the market and political practices corporations have used to grow and sustain their markets. In this paper, our aim is to understand the strategies used by the baby food industry to shape 'first-foods systems' across its diverse markets, and in doing so, drive milk formula consumption on a global scale. We used a theoretically guided synthesis review method, which integrated diverse qualitative and quantitative data sources.

Results: Global milk formula sales grew from US\$1.5 billion in 1978 to US\$55.6 billion in 2019. This remarkable expansion has occurred along two main historical axes. First, the widening geographical reach of the baby food industry and its marketing practices, both globally and within countries, as corporations have pursued new growth opportunities, especially in the Global South. Second, the broadening of product ranges beyond infant formula, to include an array of follow-up, toddler and specialized formulas for a wider range of age groups and conditions, thereby widening the scope of motherchild populations subject to commodification. Sophisticated marketing techniques have been used to grow and sustain milk formula consumption, including marketing through health systems, mass-media and digital advertising, and novel product innovations backed by corporate science. To enable and sustain this marketing, the industry has engaged in diverse political practices to foster favourable policy, regulatory and knowledge environments. This has included lobbying international and national policy-makers, generating and deploying favourable science, leveraging global trade rules and adopting corporate policies to counter regulatory action by governments.

(Continued on next page)
\end{abstract}

\footnotetext{
* Correspondence: phil.baker@deakin.edu.au

${ }^{1}$ Institute for Physical Activity and Nutrition, Deakin University, Geelong, Australia

Full list of author information is available at the end of the article
}

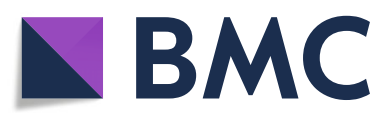

(- The Author(s). 2021 Open Access This article is licensed under a Creative Commons Attribution 4.0 International License, which permits use, sharing, adaptation, distribution and reproduction in any medium or format, as long as you give appropriate credit to the original author(s) and the source, provide a link to the Creative Commons licence, and indicate if changes were made. The images or other third party material in this article are included in the article's Creative Commons licence, unless indicated otherwise in a credit line to the material. If material is not included in the article's Creative Commons licence and your intended use is not permitted by statutory regulation or exceeds the permitted use, you will need to obtain permission directly from the copyright holder. To view a copy of this licence, visit http://creativecommons.org/licenses/by/4.0/. The Creative Commons Public Domain Dedication waiver (http://creativecommons.org/publicdomain/zero/1.0/) applies to the data made available in this article, unless otherwise stated in a credit line to the data. 


\begin{abstract}
(Continued from previous page)
Conclusion: The baby food industry uses integrated market and political strategies to shape first-foods systems in ways that drive and sustain milk formula market expansion, on a global scale. Such practices are a major impediment to global implementation of the International Code of Marketing of Breastmilk Substitutes, and other policy actions to protect, promote and support breastfeeding. New modalities of public health action are needed to negate the political practices of the industry in particular, and ultimately to constrain corporate power over the mother-child breastfeeding dyad.
\end{abstract}

Keywords: Infant formula, Milk formula, Breastmilk substitutes, Breastfeeding, Commercial determinants of health, Corporate power, Baby food industry, Lobbying, Corporate science, Food systems

\section{Background}

The commercial determinants of health $(\mathrm{CDOH})$ are receiving growing attention from researchers, advocates and policy-makers, with the purpose of informing societal responses to so-called 'manufactured' or 'industrial' epidemics, and the need to address corporate power as an urgent public health priority [1-4]. In this paper, we focus on the commercial determinants of maternal, newborn and child health. Our aim is to understand the power of the transnational baby food industry to shape 'first-foods systems' in ways that drive milk formula consumption, and in doing so, undermine breastfeeding on a global scale.

The mother-child breastfeeding dyad is a powerful force for sustainable development. As the biological 'first-food' for human children, breastmilk is safe to consume, nutritionally optimised to the child's evolving developmental needs, and protects against infection $[5,6]$. It is literally 'packaged with love' given breastfeeding fosters mother-child bonding, and reduces stress for both [7]. The breastfed child is more likely to achieve their full intellectual potential, and hence perform better at school and work in later life [8]. Near universal breastfeeding would save an estimated 823,000 deaths in children under- 5 years of age, and 98,000 maternal deaths from cancer and type- 2 diabetes every year $[8,9]$. For children, not breastfeeding increases the risk of all-cause mortality, diarrhoea, respiratory infection and dental malocclusion, and likely obesity and type- 2 diabetes, and for mothers the risk of breast cancer, and likely ovarian cancer and type- 2 diabetes [8]. To ensure child survival, optimal development and health, the World Health Organization (WHO) recommends infants initiate breastfeeding in the first hour of life, are then exclusively breastfed for 6 months, and thereafter receive nutritious and safe complementary foods, while breastfeeding continues for up to 2 years of age or beyond [10].

Yet according to UNICEF's latest estimates, just $49 \%$ of newborns initiate breastfeeding within the first hour of life, $44 \%$ are exclusively breastfed to 6 months, and $44 \%$ continue to breastfeed at 2 years of age $[11,12]$. One key explanation for these low global breastfeeding rates, is the aggressive marketing and promotion of breastmilk substitutes (BMS). Exposure to such marketing results in reduced breastfeeding initiation, exclusivity and duration, irrespective of country context [13-15]. Only a small proportion of mothers are unable to breastfeed for physiological or medical reasons, yet many more do not because they are the denied the choice, or lack the support to do so. For these reasons, BMS are made available as regulated food products [16, 17]. Milk formulas are the main type of BMS consumed worldwide, defined as foods marketed or otherwise represented as partial or total replacements for breastmilk, including any milk drinks marketed for ages $0-36$ months [18]. Categories include standard infant formula (0-6 months), follow-up formula (7-12 months), growing-up (or toddler) milks (13-36 months) and specialised formulas. By definition, milk formulas are ultraprocessed foods $[19,20]$, typically formulations of powdered milk proteins, vegetable oils, lactose and other sugars, micronutrients and cosmetic additives [21-23].

Milk formulas are implicated in child malnutrition through the displacement of breastfeeding, and through under- and over-dilution, under- and over-feeding, infection resulting from unhygienic preparation and/or microbial product contamination, and other forms of industrial contamination (e.g. China's 2008 melamine poisoning crisis) [8, 24-26]. Indeed for decades, 'bottle-baby syndrome' - a cycle of diarrhoea, dehydration and malnutrition resulting from artificial feeding in less than ideal conditions - has been reported in many countries $[6,27]$. In 1939, in her now famous speech Milk and Murder, the paediatrician Cicely Williams reported on deaths resulting from 'misguided propaganda on infant feeding' [27]. In the 1960s, the aggressive marketing and promotion of BMS contributed to precipitous declines in breastfeeding in many countries, widespread 'commerciogenic' malnutrition of the child, and potentially millions of deaths [27, 28]. This triggered worldwide public scrutiny in the early1970s, and later the birth of a transnational advocacy network - today the International Baby Food Action Network (IBFAN) - and what was to become the largest ever consumer boycott in history, against Nestlé the global market leader. Facing a public relations crisis at the time, 
in 1975 eight companies under Nestlés leadership established a lobby group - the International Council of Infant Food Industries (ICIFI) - and so began the industry's organized efforts to counter its public health opponents [27-29].

The late 1970s was also a time of accelerating globalization, and calls for new forms of international regulation, to hold increasingly powerful transnational corporations accountable [30,31]. The International Code of Marketing of Breast-milk Substitutes (The Code) [32, 33], was the first such code adopted under the auspices of the UN system, with WHO and UNICEF staff leading the stakeholder consultation and drafting process [27, 28]. Throughout this process, ICIFI and governments supporting the industry, lobbied to weaken The Code's legal status, scope of provisions and wording [27, 28]. Despite this opposition, the World Health Assembly (WHA), as the world's highest health policy-making body, adopted The Code in May 1981, with 118 member states voting in favour, three abstaining, and the US the single vote against. As the WHA resolution passed spontaneous applause erupted, and from the public gallery overlooking the plenary room a baby began to cry - a reminder to the assembled delegates 'of what was at stake' [27]. Importantly, implementation and monitoring of The Code is supported by the United Nations Convention on the Rights of the Child, and its monitoring body the Committee on the Rights of the Child [34]. The Code is a living document, strengthened biannually through WHA resolutions, in response to evolving industry practices and WHO technical guidance [27].

The Code's adoption was a laudable public health success. However, its worldwide implementation has since faced sustained industry resistance, and 40 years later, there is still a long way to go. According to the latest monitoring report, 136 of 194 reporting countries (70\%) have adopted at least some provisions of The Code into national law, but just 35 (18\%) have adopted all provisions, and 58 (30\%) have no legal measures whatsoever [35]. Furthermore, in-spite of The Code, milk formula markets have massively expanded since 1981. In earlier studies, we describe this expansion as representing a global infant and young child feeding transition to diets higher in commercial milk formulas $[8,24]$. This transition reflects transformations in the systems that structure feeding practices at the population level - what we call first-foods systems [36, 37]. Such transitions and first food systems transformations are not new phenomena. Precipitous declines in breastfeeding and the normalisation of formula-feeding in many countries throughout the mid-twentieth century, was linked with among other things, income growth, urbanization, the shift in women's work outside of the home, processes of medicalization, and intensified commercial marketing [37].
The transition we are now observing is, however, different for several crucial reasons. First, the scale-ofchange is unprecedented. Growth in formula-feeding is occurring predominantly in industrialising middleincome countries, home to the world's largest child populations. Between 2005 and 2019 alone, the world sales volume more than doubled from 1 to 2.2 million tonnes per annum, a rate that far exceeds changes in the global birth rate [38]. Second, it is occurring in the context of continuing economic globalization, including rapid growth in the size, transnational reach and consolidation of the baby food industry, with the large majority of sales accruing to just a small number of 'Big Formula' corporations [37, 39]. These corporations are reportedly using intensive and sophisticated marketing techniques to reach mothers, and to grow their markets on a global scale [39-41]. Despite these developments, surprisingly little attention has been paid to understanding the globalization of this industry, nor the market and political strategies Big Formula uses to expand, sustain and protect its markets, with some exceptions [42-45]. The role of the wider 'baby food industry', including dairy and other ingredients suppliers, advertising and public relations agencies and so on, throughout the supply chain, is also not well understood.

In this paper we address key questions. Who is Big Formula and the transnational baby food industry? How has this industry evolved, and how is it now organized across markets and globally? What strategies has the industry used to shape first-foods systems, and in doing so, drive milk formula consumption on a global scale? How can we understand the market and political practices of the industry in terms of power, and in doing so, inform new modalities of public health action?

\section{Materials and methods}

Although the literature on Big Formula's marketing practices is extensive, there are limited studies on the wider market and political practices of the industry. We therefore adopted a synthesis review method that allowed us to draw from extant literature, but also to integrate new qualitative and quantitative data to address gaps in knowledge. This involved several steps: i) development of a theoretical framework to guide the study; ii) search for relevant academic and grey literature; iii) data collection and descriptive statistics; and, iv) development of themes and synthesis of final results.

\section{Theoretical framework}

We have defined and described the main components of first-foods systems in our earlier work [36, 37]. To understand the power of the baby food industry to shape first-foods systems, we integrated concepts from the 
Table 1 Theoretical framework used to understand corporate power and guide the study

\begin{tabular}{|c|c|c|c|c|c|}
\hline \multirow{2}{*}{$\begin{array}{c}\text { Source of } \\
\text { power }\end{array}$} & \multirow{2}{*}{$\begin{array}{c}\text { Forms of } \\
\text { power }\end{array}$} & \multicolumn{4}{|c|}{ Actors \& relations of power } \\
\hline & & Market actors & State actors & Civil society & Experts \\
\hline \multirow{3}{*}{$\begin{array}{l}\text { Material } \\
\text { assets and } \\
\text { resources }\end{array}$} & Instrumental & & & & \\
\hline & Structural & Thet & \multirow{2}{*}{ 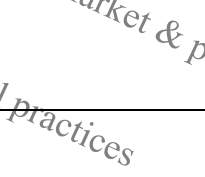 } & & $i_{i c_{a j}}$ \\
\hline & Discursive & & & ${ }^{c t} i_{e}$ & \\
\hline \multicolumn{6}{|c|}{ Contextual factors (amplify or constrain power) } \\
\hline \multicolumn{6}{|c|}{ Political, legal, technological, economic, and socio-cultural } \\
\hline
\end{tabular}

$\mathrm{CDOH}$ and political economy of food systems literatures (Table 1) [4, 46-49].

First, we defined corporate actors, something often missing in $\mathrm{CDOH}$ scholarship. 'Big Tobacco' is often used as a collective term for the world's largest tobacco manufacturers. Similarly, we used 'Big Formula' to refer to the corporations that manufacture and distribute BMS on an industrial scale, most but not all, being transnational corporations with a market presence in two or more country markets. We also viewed each corporation as anchored in their country of origin, and hence as identifying with nationally-derived cultures, operational structures and relationships with their home country governments $[50,51]$. The 'baby food industry' comprises Big Formula at its core, but also the dairy industry and other input suppliers, retailers, advertising agencies, and various other commercial entities who profit from BMS [21, 23].

Executives and senior management run corporations, with a fiduciary duty to maximise profit, and through sustained profit, generate returns to shareholders (the owners) $[50,51]$. To realise this interest, every effort is made within the legal constraints the corporation operates under, and sometimes beyond these constraints, to externalize as much of its costs of production as possible. The functioning of the market economy ensures these costs (or in economic terms 'externalities') are in the public domain, and so must be addressed by governments, or absorbed by social groups (e.g. higher morbidity, and health care costs) and/or the environment (e.g. water pollution or greenhouse gas emissions from dairy production). In pursuit of their interest, corporate actors seek to minimise conflict, neutralise or co-opt other societal actors, be they market (e.g. consumers, competing firms or suppliers), state (e.g. governments and intergovernmental organizations), civil society (e.g. nongovernmental organizations, social movements and the media), and expert (e.g. scientists, academics and health professionals) actors [52].

Scholarship on the tobacco, alcohol and ultraprocessed food industries often refers to a set of market and political practices (i.e. applied strategies and tactics) used to influence other actors within the system [2, 46, $53]$. We organized these same practices under several overlapping and reinforcing concepts of power.

Arguably, the main source of corporate power is material, referring to the assets and resources acquired by corporations over time [47, 54]. With regards to Big Formula, we considered inter alia their sales revenues, profits, finance, productive assets (e.g. factories), human resources, trademarks and proprietary technologies among others. As corporations grow and globalize, these accumulating assets and resources can be readily converted into instrumental, structural and discursive forms of power. Instrumental power is the power to influence others directly $[47,48,55]$. For example, we anticipated that corporate executives may be members of elite social networks, with direct access to political leaders and government officials. Furthermore, that Big Formula uses its resources (and also 'pool resources' across the industry) to hire lobbyists, lawyers and public relations firms, make political donations, recruit former governmental officials, finance front groups and think tanks, form business coalitions, employ large sales forces to engage health professionals, and so on.

Structural power is the power to shape agendas and control the behavioural options available to others, without taking direct action [48, 49, 55]. For example, 
governments might make regulatory concessions to attract (or retain) the investments and employment opportunities Big Formula provides. In a strategy known as policy substitution, corporations might adopt voluntary private standards to delay or even replace regulation by the state; or support public-private partnerships (PPPs), that expand corporate influence in defining policy agendas and decision-making. As markets become more consolidated, Big Formula might exert greater power over suppliers to reduce costs (i.e. oligopsonistic power), control the product types and prices available to consumers (i.e. oligopolistic power), and thereby maximise its profit margins. Discursive power is the power to shape attention, influence (or supress) knowledge and evidence, and frame debates $[48,49,55]$. It is the power to socialise others, often unconsciously, into accepting certain problem interpretations and behaviours as normal, acceptable or socially desirable. To this end, we anticipated that Big Formula might finance public relations initiatives, attempt to shape scientific processes and wider knowledge environments, and engage in sophisticated forms of marketing.

We viewed these forms of power as interacting. For example, to counter regulatory threats, lobbyists may coordinate their discursive strategies across multiple decision-making spaces simultaneously; private standards can be both a form of structural power by substituting for regulation by the state, and discursive by portraying corporations as responsible social actors; marketing not only influences and drives consumer behaviour, but also socialises health professionals, policymakers and others into adopting pro-industry beliefs. Wider contextual factors support or constrain corporate power, including the political, legal, technological, economic, and socio-cultural structures and systems in which they operate $[56,57]$. For example, we anticipated that trade and investment liberalization has enabled Big Formula's global expansion, including its cross-border supply chains, while the expanding scope and depth of trade agreements has constrained the 'policy space' of governments to regulate formula markets within their borders $[19,58]$. Inadequate paid maternity leave entitlements in many countries, enables Big Formula's power, by making formal maternal employment less compatible with breastfeeding. We viewed a major constraint on the power of Big Formula as the norm-promotion and accountability work of civil society groups (e.g. IBFAN), international organizations (e.g. WHO, UNICEF) and others $[37,59]$.

\section{Qualitative data collection}

To source existing literature, we applied a semi-systematic branching search strategy, considered appropriate given the complexity of the topic, and the need to discover and draw from diverse literature sources.

First, we searched scholarly and web databases with comprehensive coverage of health, economic and social science sources, including PubMed, Scopus, Web of Science, EconLit, Eldis, Google Scholar and Google. We used relevant IYCF-related search terms (e.g. breast milk substitute*, formula*, breastfeed*), combined with actorrelated (industr", compan*, corporat*, commercial", government*, state, civil society), and policy and practicerelated (e.g. politic*, policy, marketing, advertising, promotion, public relations, lobby*, donation*) terms, with no date limits.

Second, to source grey literature, we searched the websites of WHO, UNICEF, FAO, UNSCN, Codex Alimentarius Commission (CAC), World Bank and World Trade Organization; and the civil society organizations IBFAN, Helen Keller International, FHI 360 / Alive \& Thrive and Save the Children. We sourced industry reports from Euromonitor Passport, and from company and trade association websites.

As our understanding of the topic evolved, and reference lists were examined, further branching searches were conducted until we reached saturation (i.e. minimal new data was found with each additional search). This iterative process resulted in further discovery of media articles and internet sources.

Documents were included if published in English, relevant to the study aim, with described objectives, a clear method (if applicable), and conclusions substantiated by the findings.

\section{Quantitative data collection}

Quantitative data was collected from diverse sources.

To describe the material assets and resources of companies, we sourced data from market databases, triangulated where possible with data from company websites and annual reports. Data on milk formula sales volumes (kilograms) and values (US\$ at fixed exchange rates and current prices) for the years 2005-18, and data on market share (\% market sales attributed to global company) for the years 2010-18, were sourced from the Euromonitor Passport database, for the world's largest 78 country markets [60]. We have described this data extensively elsewhere [19, 24]. Data on total company sales, profits and assets, global rankings, and employee numbers were sourced from Compustat Industrial [61], Fortune 500 [62], and Forbes Global 2000 [63].

To understand the industry's evolving global production and distribution networks, we used milk formula sales data from Euromonitor Passport, and sourced trade flow (imports and exports in US\$) data from UN Comtrade [64], using HS Code 190110 for the years 2005-17. We then generated milk formula production estimates 
by adding the net-export value to the total sales value for each country/year (given total sales = production exports + imports). To understand the industry's evolving sourcing networks, data on dry milk powder production values (tonnes) were sourced from FAOSTAT [65], using codes 897 and 898, and trade flows (imports and exports in US\$) from UN Comtrade using HS Codes 040221, 040229, and 040210.

To understand Big Formula's global network of trade associations (i.e. lobby groups), we sourced initial 'seed' data from trade association membership disclosures listed on company websites, and then sourced additional membership data from those trade association websites, further snowballing until no new data was generated. We recorded 'membership' as reported on websites at the time of data collection, and hence this may data may not represent actual membership at the time of publication, nor can we validate the accuracy of content sourced from these websites.

To better understand the role of industry in shaping global regulatory standards for BMS at the CAC, we enumerated the number of member state delegates and observers from governments, international organizations, industry groups and public-interest non-governmental organizations attending the Codex Committee on Nutrition and Foods for Special Dietary Uses (CCNFSDU). We extracted data on the listed affiliations and/or email addresses found in CCNFSDU meeting agenda documents, available on the CAC website [66].

Early in our investigation it became apparent the US Government, representing the interests of the US-based corporations and dairy industry, has had a disproportionate influence in shaping relevant international standards, and constraining worldwide implementation of The Code. To further understand the lobbying power of the corporations in the US, we sourced data from the Centre for Responsive Politics [67]. This included total lobbying expenditures (US\$) by market leading corporations, for the years 1998-2019, and US Government branches and agencies targeted by this lobbying; and lobbying expenditures (US\$) declared as BMS- or trade-related, and the number of lobbyists employed, for the years 2007-18.

\section{Analysis and synthesis}

All documents were uploaded to the qualitative analysis software NVivo (QSR International) and, guided by the theoretical framework, coded using constant comparative analysis by the lead author. This involved establishing, integrating and/or adding to the coded concepts over several iterations of coding the documents [68]. Given the large number of sources used, and the complexity of the topic under study, we did not use multiple-coders nor assess coder reliability. These techniques were used more to organize and retrieve the qualitative data, and to develop and refine emergent themes. We generated descriptive statistics using Excel (Microsoft) and R version 3.6.2 (Foundation for Statistical Computing). Network graphs were generated using Gephi version 0.9.2 (Association Gephi). Finally, we synthesised the qualitative and quantitative data into a final set of themes, which are presented in the results.

\section{Results}

The following section presents the results, organized into key themes. We did not find significant recent literature on this topic. Therefore, in many places we draw upon and present new empirical findings.

\section{The rise of big formula and the material foundations of its power}

In this section we describe the evolution of the baby food industry, and in doing so, describe the material assets and resources the corporations have accrued, as milk formula markets have expanded worldwide.

Today, Nestlé, Danone, Reckitt Benckiser Mead Johnson (RBMJ), Abbott Laboratories (Abbott), Friesland Campina (RFC) and Feihe are the global market leaders. Table 2 provides a breakdown of their assets and resources. Although pharmaceutical companies have historically dominated the industry, especially in the US and reflecting the unique nature of the product 'on the dividing line between food and pharmaceuticals' [21], Big Formula now spans the pharmaceutical, food manufacturing and consumer goods sectors. The top-five are extensively globalized. Nestlé, Danone, Abbott and RFC are present in $>100$ country markets and RBMJ in 50, with affiliate or subsidiary firms in most. Nestlé has a near ubiquitous global presence. With the exception of Feihe, which operates in China alone, Big Formula are transnational corporations headquartered in Europe or the US. In 2016 all corporations, with the exception of Abbott, generated the majority of sales in emerging markets (Table 2).

None sell BMS exclusively, comprising between 10 and $33 \%$ of total sales. However, the category has been a major, and if not the main, source of new revenue growth. For example, in 2018 the Nestle Nutrition and Health Science division was the second largest contributor to total global sales, but the most important for generating new sales growth [69]. Big Formula also includes other transnationals such as Kraft Heinz (US) and Groupe Lactalis (France), and important regional players such as Hipp and Hero Group in Europe. National firms are leaders in several markets, for example, Vinamilk in Vietnam, Meiji and Morinaga in Japan, and Namyang in South Korea. China is home to several large homegrown corporations [38]. Big Formula are major employers, with the largest-five employing $~ 580,000$ people between them worldwide. For Nestlé, Danone and 
Table 2 Material assets and resources of the world's largest Big Formula corporations

\begin{tabular}{|c|c|c|c|c|c|c|}
\hline Corporation & $\begin{array}{l}\text { Nestlé } \\
\text { (Gerber / Wyeth) }\end{array}$ & $\begin{array}{l}\text { Danone } \\
\text { (Nutricia) }\end{array}$ & $\begin{array}{l}\text { Reckitt } \\
\text { Benckiser } \\
\text { (Mead Johnson) }\end{array}$ & $\begin{array}{l}\text { Abbott } \\
\text { Laboratories (Abbott) }\end{array}$ & $\begin{array}{l}\text { Royal } \\
\text { Friesland } \\
\text { Campina }\end{array}$ & Feihe \\
\hline \multicolumn{7}{|l|}{ General } \\
\hline Headquarters & Switzerland & France & USA / UK & USA & Netherlands & China \\
\hline Sector(s) of origin & $\begin{array}{l}\text { Food } \\
\text { manufacturing }\end{array}$ & $\begin{array}{l}\text { Dairy / Food } \\
\text { manufacturing }\end{array}$ & $\begin{array}{l}\text { Consumer } \\
\text { goods }\end{array}$ & Pharmaceuticals & $\begin{array}{l}\text { Dairy / Food } \\
\text { manufacturing }\end{array}$ & $\begin{array}{l}\text { Food } \\
\text { manufacturing }\end{array}$ \\
\hline Year founded & 1867 & 1919 & $1905^{\gamma}$ & 1888 & $1879^{\delta}$ & 1962 \\
\hline Global 500 ranking (2018) & 76 & 426 & - & 103 & - & - \\
\hline Total assets (US\$ millions) 2018 & 139,244 & 52,096 & 44,399 & 67,173 & 10,403 & 1791 \\
\hline $\begin{array}{l}\text { Total intangible assets } \\
\text { (US\$ millions) } 2018^{a}\end{array}$ & 51,155 & 28,828 & 35,705 & 42,196 & 2014 & 7 \\
\hline Total sales (US\$ millions) 2018 & 93,242 & 29,070 & 14,855 & 30,578 & 13,940 & 1,570 \\
\hline $\begin{array}{l}\text { Profits (EBITDA) (US\$ millions) } \\
2018\end{array}$ & 18,475 & 5276 & 4363 & 7562 & 889 & 432 \\
\hline Number of employees (foreign) & $308,000(298,000)$ & $\begin{array}{l}105,783(98, \\
378)\end{array}$ & $42,400(38,746)$ & 103,000 (---) & $\begin{array}{l}23,816(\sim 16 \\
000)\end{array}$ & - \\
\hline \multicolumn{7}{|l|}{ BMS-specific } \\
\hline $\begin{array}{l}\text { World BMS market share \% (retail } \\
\text { sales value) } 2018 \text { (2010) }\end{array}$ & $17.9(13.8)$ & $13.5(12.1)$ & $10.6(12.9)$ & $9.7(11.5)$ & $5.1(2.7)$ & $4.8(1.4)$ \\
\hline $\begin{array}{l}\text { World BMS sales value (\$US } \\
\text { millions) } 2018 \text { (2010) }\end{array}$ & $9373(3567)$ & $7093(3126)$ & $5579(3340)$ & 4097 (2985) & 2796 (706) & 2505 (354) \\
\hline BMS sales as \% of total sales 2018 & 10.0 & 25.5 & 33.7 & 13.4 & 20.8 & - \\
\hline $\begin{array}{l}\text { Number of countries with } \\
\text { products }\end{array}$ & 190 & $120+$ & 50 & $160+$ & $100+$ & 1 \\
\hline BMS brands sold worldwide & 22 & 18 & 10 & 7 & 5 & 1 \\
\hline $\begin{array}{l}\text { BMS brands with > } 1 \% \text { world } \\
\text { market share }{ }^{\beta}\end{array}$ & $\begin{array}{l}\text { NAN, Illuma, S-26, } \\
\text { Nido }\end{array}$ & $\begin{array}{l}\text { Aptamil, } \\
\text { Nutrilon, SGM }\end{array}$ & $\begin{array}{l}\text { Enfamil, } \\
\text { Enfagrow }\end{array}$ & $\begin{array}{l}\text { Similac, Pediasure, } \\
\text { Eleva }\end{array}$ & Friso & Firmus \\
\hline $\begin{array}{l}\% \text { sales from emerging markets } \\
2016 \text { (\% from developed markets) }\end{array}$ & $71.5(28.5)$ & $65.3(34.7)$ & $52.3(47.7)$ & $42.6(57.4)$ & $92.8(7.2)$ & 100 \\
\hline $\begin{array}{l}\text { Markets with subsidiary / } \\
\text { affiliate firms }\end{array}$ & 114 & 77 & 28 & 89 & 36 & - \\
\hline \# employees in BMS division & - & 21,000 & - & - & 2348 & - \\
\hline
\end{tabular}

Notes: Financial data sourced from Compustat, Fortune 500, Forbes, company annual reports and financial statements; data on compliance with The Code from Access to Nutrition Index; market share and sales data from Euromonitor Passport; currency conversions were made using 2018 average currency rate for the relevant financial year; $\alpha=$ intangible assets refer to non-physical assets, including brand recognition and intellectual property, such as trademarks, copyrights and patents; $\beta=$ most brands include standard, follow-on, toddler and specialised milks under the same name; $\gamma=$ founding date of Mead Johnson, acquired by Reckitt Benckiser in 2017; $\delta=$ the parent companies Friesland Foods and Campina merged in 2008, but were founded in 1879 and 1979 respectively

RBMJ, only a small fraction $(<10 \%)$ are in their home countries. Approximately one fifth of Danone's workforce, and one tenth of RFC's, are employed in the division that manufactures BMS.

Until the mid-nineteenth Century babies were breastfed, or due to the mother's death in childbirth, for other medical reasons or by choice, they were often wetnursed by another woman. In some contexts, wetnursing was an organized and regulated profession. In others, it was a service provided by family members, by slaves for their masters, or by poor women for the rich $[6,70,71]$. Artificial feeding of animal milks or other liquid foods also occurred, however it often resulted in malnutrition and high infant-mortality, exacerbated by poor sanitation and food hygiene [71, 72]. It was in this context the German chemist Justus von Liebig patented the first milk formula in 1865, informed by studies on the chemical composition of cows and human milk. By 1869, Liebig's food for infants was being sold in Europe and the US, made from cow's milk, malt and wheat flour, and potassium bicarbonate, and available first in liquid and then in powdered form, and purchased mostly by the wealthy. New techniques and materials for manufacturing bottles and teats, helped to promote the normalisation of artificial feeding, and supported early market expansion. By 1883, at least 27 patented brands 
of infant food had become available, and the age-old profession of wet-nursing quickly declined [70, 71].

Henri Nestlé, the founder of the company bearing his name, pioneered many of the industry's early marketing techniques, including 'direct mail' of brochures to new mothers, and a 'medical strategy' of engaging doctors, conducting clinical trials, advertising in medical journals, and product endorsement by prominent scientists and health professionals [73]. Nestlé, and other companies like Britain's Cow and Gate, were at the vanguard of the industry's first-wave of globalization, expanding along European colonial pathways, and benefiting from their 'first-mover advantage' in many markets $[74,75]$. By the 1920s, Nestlé was by far the market leader, with 80 factories operating worldwide, plus 300 sales offices, depots or agencies [76]. By this time, most of today's commercial milk formula brands had become available [27, 71]. This included specialised milks for certain medical conditions affecting a small proportion of infants, the first using soy-based protein for those allergic to cow's milk [77]. Milk formula markets steadily expanded throughout the mid-twentieth century, alongside more intensive marketing to health professionals, the medicalisation of pregnancy and birth (including the frequent separation of mother and infant in birthing clinics), and the widespread use of formula in hospitals. These developments coincided with a precipitous decline in breastfeeding in many countries, reaching historic lows in the 1960s-70s [71].

From then onwards, however, breastfeeding rates began to resurge in many of Big Formula's markets. This along with declining birth rates following the postWorld War II 'baby boom', resulted in stagnating sales, and in response, companies started to intensify their marketing practices in markets of the Global South [27, 52]. Marketing techniques used to promote and normalise formula-feeding, included mass-media advertising, large-scale distribution of free samples, and salespeople dressed as 'mothercraft nurses', to engage mothers directly in maternity wards and in their homes [27, 28]. These practices were soon associated with widespread 'commerciogenic malnutrition' and infant deaths [6,28], which in-turn triggered worldwide civil public scrutiny, and events that would lead to the adoption of The Code in 1981. Despite these developments, market expansion continued apace. Between 1978 and 1983, total world sales nearly tripled, from $\sim$ US $\$ 1.5$ billion to $\sim$ US $\$ 4$ billion [78], mainly through exports to overseas markets, as Big Formula took advantage of subsidies for dry milk products in the US and Europe [29]. In 1984, facing new marketing regulations promulgated by The Code, the industry began marketing more intensively a wider range of product categories for older infants and young children. The availability of follow-up (6-12 months) and toddler (13-36 months) formulas markedly increased $[27,79]$, and in many markets today these categories now represent a near-equal, or even greater, market share than infant formula [80].

The Code was, in some respects, a product of its time. The 1970s-80s was an era of accelerating globalization, with rapid growth in the number and size of transnational corporations, and their economic power relative to nation states [30,51]. With this came vocal calls from civil society, many governments, and various UN agencies, for the internationalisation of corporate regulation, with The Code being one among $~ 30$ such codes and guidelines proposed across the UN system at the time $[30,31]$. Remarkable changes in the global political and economic system have occurred since then. In the 1980s, the rise of neoliberal economic and social policies led to market liberalization, privatization and growing preferences for market-based approaches to governance [81, 82]. A 'corporate food regime' emerged, as transnational food corporations, mostly through foreign direct investment, began to globalise with renewed vigour, seeking growth opportunities in the rapidly industrialising countries of the Global South [48, 83, 84]. The establishment of the World Trade Organization (WTO) in 1995, and then an explosion in free trade agreements, accelerated this process, allowing such corporations to integrate their 'global value chains', while imposing new rules on how governments regulated their markets [85-87].

The above developments fostered ripe conditions for the most recent and remarkable phase of Big Formula's global expansion. As shown in Fig. 1, this is reflected in the massive expansion in worldwide milk formula production and trade flows. In 2005, only Ireland and Singapore were exporting $>$ US $\$ 5$ million of milk formula for retail sale to China; by 2017 at least 16 countries were - most notably Australia, New Zealand, France, and the Netherlands. In 2005, total world sales were US $\$ 22.9$ billion; by 2019 this figure had more than doubled to US $\$ 55.6$ billion [37, 38]. The world sales volume per child (0-36 months), more than doubled from 3.5 to $7.4 \mathrm{~kg}$ over the same period. This growth occurred mostly in the industrialising and highly-populated middle-income countries of East and South East Asia, and to a lesser extent Eastern Europe \& Central Asia, Middle East \& North Africa, and Latin America. During this period, China became the world's largest and most competitive market. In 2005, the US was the world's largest market and China represented just $14.1 \%$ of global sales. By 2019, it represented 32.5\%, 2.3-fold larger than the US and Western European markets combined [38].

Today Big Formula is 'hyper-globalized' [87], with extensive global sourcing and production networks. In 2018, for example, Nestlé had 443 factories operating across 80 countries, of which 40 were listed as the 


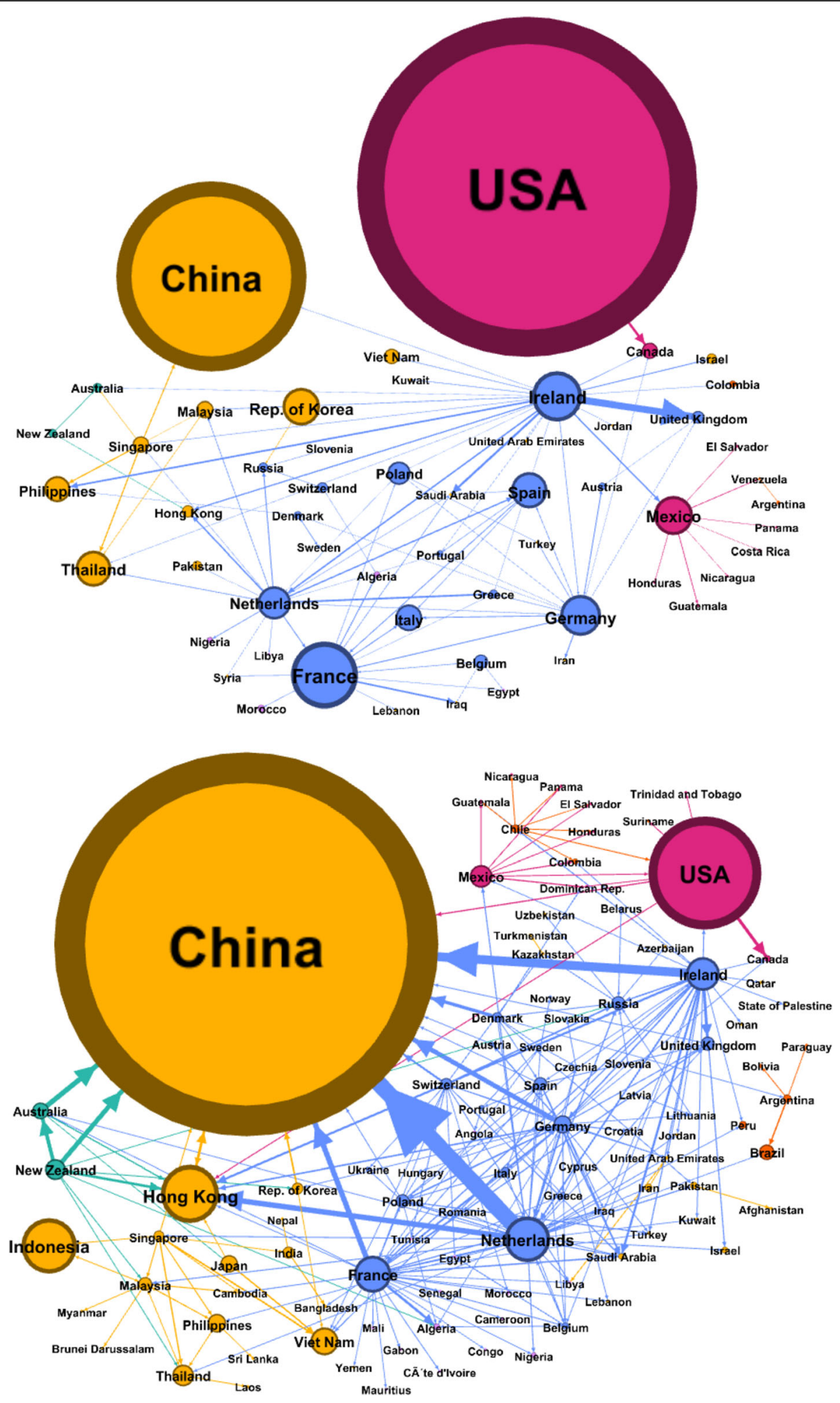

Fig. 1 Changes in global milk formula production and trade flows (US\$), showing 2005 (top) and 2017 (bottom); circles represent country production values and lines the value and direction of trade. Notes: To simplify the figure, only countries with trade flow values $>$ US $\$ 5$ million were represented; milk formula sales data were sourced from Euromonitor Passport; trade data were sourced from UN Comtrade 
division that manufactures BMS [69]. Abbott operated 27 production sites globally, of which 14 were listed under its Nutrition division [88]. Market expansion has also been enabled by massive growth in the industries providing milk formula manufacturing inputs. Between 1961 and 2014, for example, production of dry milk powder grew from 491,000 to $3,444,000 \mathrm{t}$, initially from output in European countries, and then from countries in Australasia and Latin American with industrial dairying systems $[89,90]$. Figure S1 shows the significant expansion in dry milk powder production and trade flows between 2005 and 2014. Markets for dry milk powder are dominated by a handful of 'Big Dairy' corporations, including for example, Fonterra (New Zealand), Dairy Farmers of America (US), and Groupe Lactalis (France). China's formula boom was enabled by expanded dairy production and exports from New Zealand in particular, which expanded rapidly following the Free Trade Agreement signed between the two countries in 2008. New Zealand was the first country to sign such an agreement, and by 2012, dairy exports comprised $30 \%$ of the country's total exports to China [91, 92]. In recent decades vegetable oil production, and especially palm oil as a common milk formula ingredient, has also significantly expanded [19, 93].

The rise of Big Formula's material power is also reflected in high levels of market concentration nearly everywhere. Figure 2 shows the market shares of leading corporations in key country markets and worldwide. In $2018,61.6 \%$ of world sales accrued to the six largest milk formula manufacturers listed in Table 2. The three largest - Nestlé, Danone and RBMJ - had a combined world market share of $42 \%$. In 2010, the largest four had near equivalent sales, but since then Nestlé and Danone have further consolidated their market positions. These gains have occurred through organic sales growth, but also through sustained merger and acquisition activity, with the industry currently undergoing 'terminal' consolidation [21]. Recent acquisitions have included Danone's of Numico/Nutricia in 2007 for US\$18 billion, Nestlé's of Pfizer's infant nutrition division in 2012 for US\$11.9 billion, and Reckitt Benckiser's of Mead Johnson Nutrition in 2017 for US\$16.6 billion. The acquired firms were already products of various mergers and acquisitions, going back many decades [21]. Regional and national markets are even more consolidated. As shown in Fig. 2, many are oligopolistic, for example in the US, Brazil, South Africa and Indonesia, where only a few corporations dominate. The exception is China, where Nestlé leads, but a diverse mix of transnational and domestic players compete [21]. Consolidation can enhance Big Formula's market power over suppliers, allowing the sourcing of manufacturing inputs at lower-cost. By capturing markets, companies can also exert greater control over prices, and what products are available to consumers.

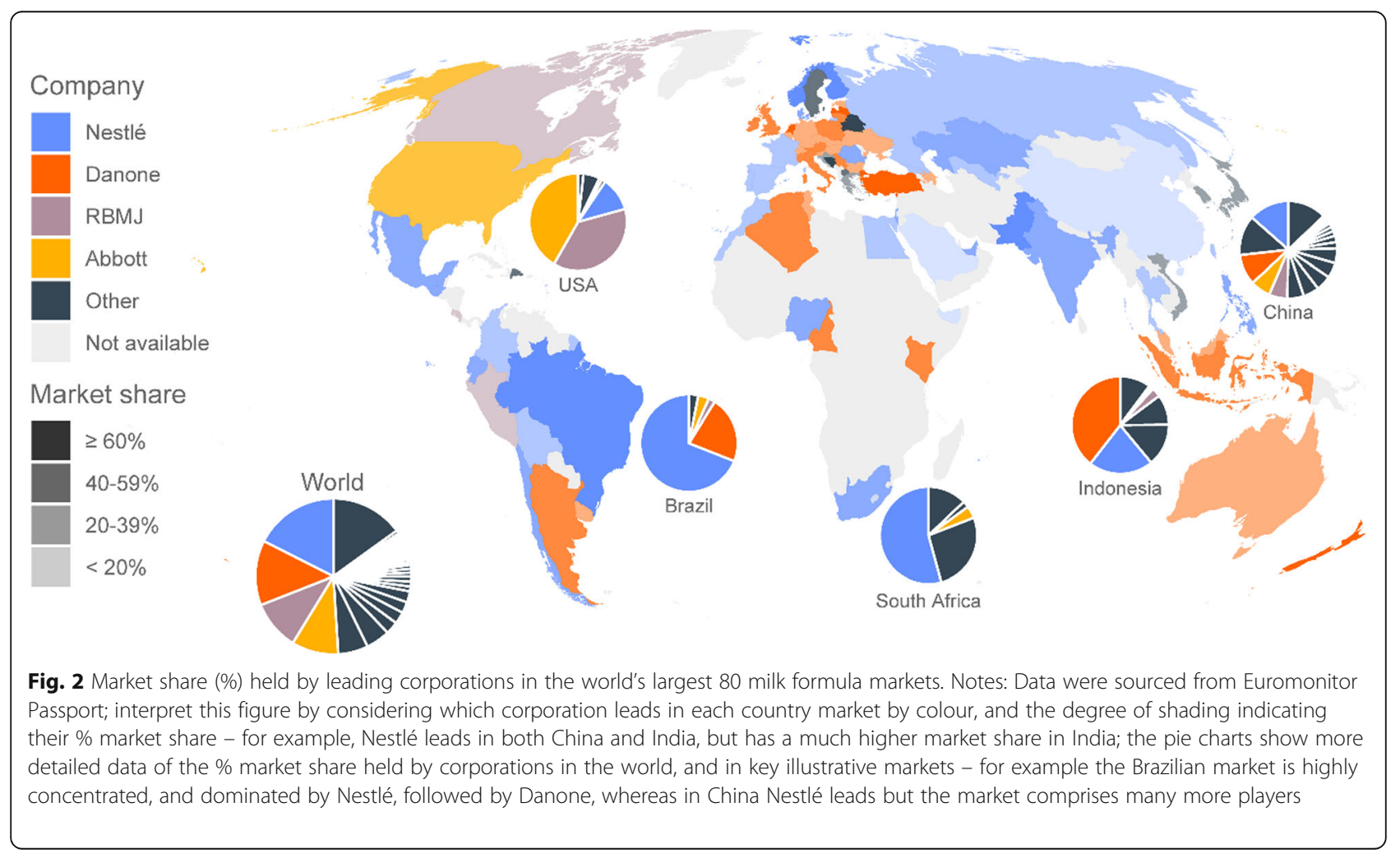


Several transformations in Big Formula's distribution networks, also explain the phenomenal global expansion of milk formula markets. First, the liberalization of trade in retail services has enabled the 'supermarketization' of developing countries since the late 1990s, which alongside pharmacies, is a key channel for reaching urban consumers with rising incomes [19, 24]. Second, the medicalization of pregnancy, birthing and infant care in many countries, has created new opportunities for the industry to market products through health-care providers (see health professional co-optation), just as new practices that undermine breastfeeding, such as birth by caesarean section, have increased markedly in many countries [37, 94]. Finally, growth in 'grey-market' trade by third parties has also contributed significantly to rapid market expansion [24, 37]. Sophisticated Daigou (grey channel) operations in Australia, New Zealand, the UK and Germany have involved shoppers purchasing well known branded products for export in suitcases or small shipments to China, to the extent that in 2014, Daigou sales were equivalent to half of what foreign companies were selling in the formal Chinese market [42].

\section{The baby food industry's global influence network}

To protect their worldwide interests, and to foster favourable regulatory and knowledge environments for expansion across their diverse markets, Big Formula and the wider industry employs an extensive global network of trade associations and other corporate-funded influence organizations. Figure 3 shows this network and Table S1 the full list of names and abbreviations. The lines represent membership in these organizations, which span many regulatory issues and corporate functions, at international, regional and national levels; the size of the circles represents the number of organizations each corporation associates with. The respective corporations are typically members of organizations in countries where they have a major market presence. Hence Nestlé, as the most transnationalised (Table 2), is a member of the most organizations in the network followed by Danone, RBMJ, Abbott and RFC. Major ingredients suppliers, such as DSM and Fonterra, also feature prominently.

Core to the network are 'infant nutrition' trade associations (red), which focus on baby food issues specifically. The first such organizations were established in the 1970s in response to emerging public relations and regulatory threats, enabling Big Formula to execute their public relations strategies and lobby at 'arms-length distance', while minimising negative publicity. The International Council of Infant Food Industries (ICIFI) was established by eight companies in 1975, following highly publicised Nestlé litigation against student activists in
Switzerland [27, 28]. As civil society groups began to strongly agitate for adoption of The Code, ICIFI enabled Nestlé to make 'third party rebuttals of the activists' case' [96]. However, because of this, ICIFI's public reputation soon diminished, and it was replaced in 1984 by the International Association of Infant Food Manufacturers (IFM) [97, 98].

The IFM itself was disbanded in 2016 and today the International Special Dietary Industries (ISDI) is the industry's peak international lobby group, with 20 member associations across six continents [99]. Two of these associations are regional - Specialised Nutrition Europe and The Asia Pacific Infant and Young Child Nutrition Association. Some have authoritative names, akin to professional and non-commercial organizations - for example, the Infant and Pediatric Nutrition Association of the Philippines, the Infant and Young Child Nutrition Council (India), and the Infant Nutrition Council of Australia \& New Zealand. Some provide extensive infant and young child feeding advice on their websites. Others have developed clinical standards and guidelines for infant care. For example, Abbott provided seed funding to establish the European Foundation for the Care of Newborn Infants (EFCNI), 'to represent the interests of preterm and newborn infants and their families' [100]. Hence, these 'front groups' appear to be public-interest civil society organizations, but in fact represent corporate interests [46].

Figure 3 shows the influence network also includes trade associations and lobby groups concerned with many other corporate issues and regulatory affairs. In yellow, for example, is a network of advertising and branding associations, many of which are member organizations of the World Federation of Advertisers (WFA). The activities of these organizations are diverse, but mainly focus on protecting the intellectual property rights of corporate brands, promoting voluntary advertising codes, and lobbying against governments adopting mandatory marketing regulations. Other types also feature prominently in the network including general business associations like the US and European Chambers of Commerce, who seek to foster trade access and protect free enterprise (brown), food, beverage and grocery manufacturers associations (green), dairy groups like the International Dairy Federation (blue), and corporatefunded scientific institutes and communications platforms, for example the International Life Sciences Institute (ILSI) and the International Food Information Council (IFIC) (purple).

\section{Contesting standards in multi-lateral policy-making arenas}

The lobbying activities of many organizations in the above network, are coordinated across multiple policy fora and decision-making spaces simultaneously. 


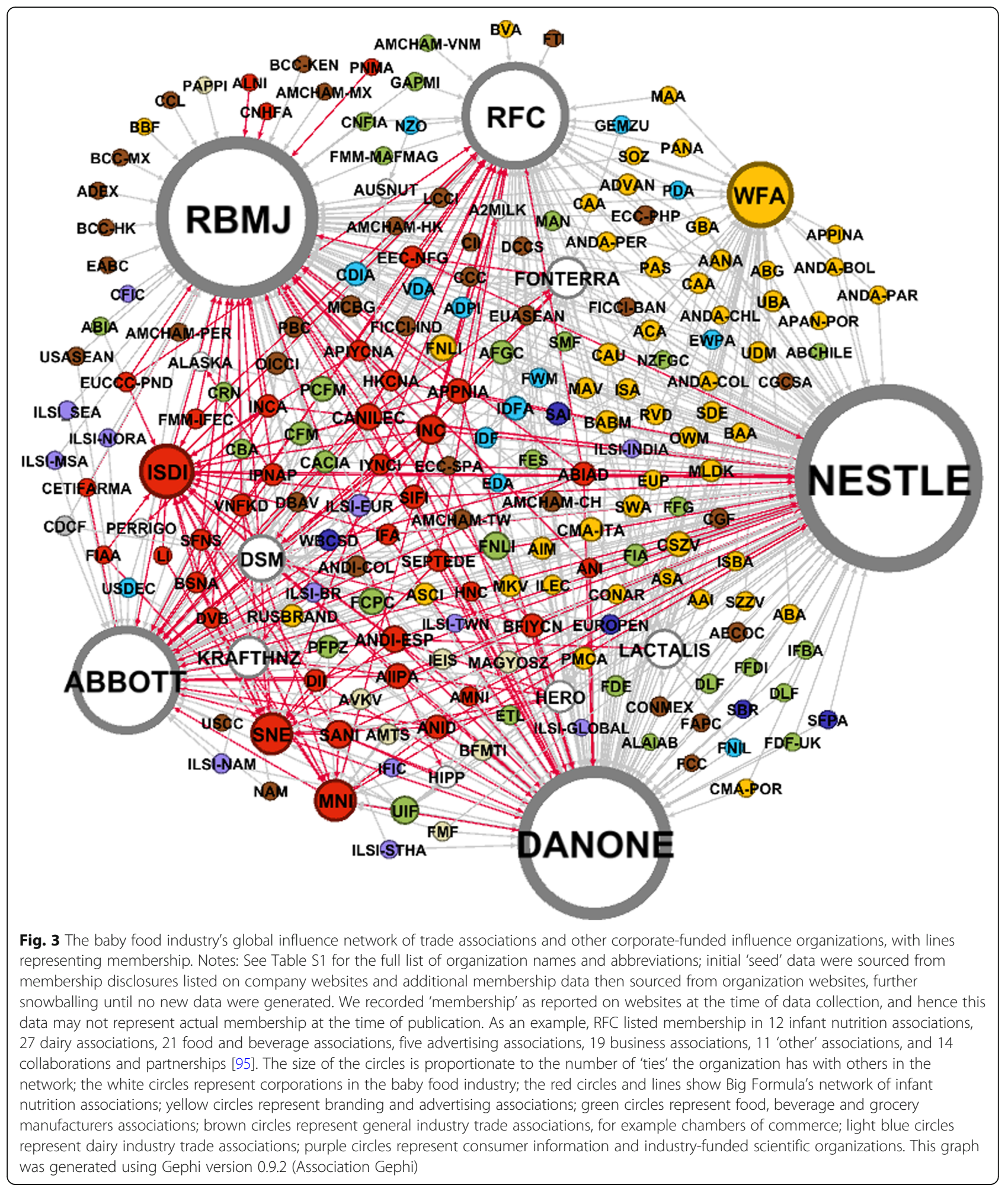

At the international level, this includes three key organizations that develop policy and govern the regulation of foods for infants and young children, and hence influence industry sales worldwide: the World Health Organization (WHO), Codex Alimentarius
Commission (CAC), and World Trade Organization (WTO).

Technical standards and norms established by the WHO, are crucial in guiding global infant and young child feeding (IYCF) policy actions. Table 3 provides 
Table 3 Actions by or on behalf of the baby food industry in relation to key multi-lateral organizations that govern the regulation of foods for infants and young children

\begin{tabular}{ll}
\hline Targeted organization & Objective (inferred) \\
\hline World Health & $\begin{array}{l}\text { Weakening the initial scope and strength of } \\
\text { Organization }\end{array}$ \\
The Code
\end{tabular}

\section{Description}

In 1980, ICIFI hired Stanislaus Flache, a former assistant director-general of WHO, in order to gain insider knowledge and lobby WHO officials during the consultation and drafting process. Flache was quoted as stating 'We oppose the universal code and some believe it is a sign that the UN system is moving to control multinationals' [28]. ICIFI worked to dilute language during the drafting process [29]. A letter was sent to members of the WHO Executive Board, who were meeting in January 1981 to approve a draft document, stating the 'World Industry has found this present draft code unacceptable... highly restrictive...irrelevant and unworkable' and that 'various provisions...could have a negative effect on child health' [28]. In April, ICIFI circulated another letter stating the draft was 'too detailed, counterproductive and, in parts, incompatible with the constitutional requirements of a number of countries' [44]. US officials were engaged to lobby other member state delegates and WHO staff on the industry's behalf. Major dairy-producing countries rejected initial drafts, including the US, Denmark, France, Netherlands, New Zealand and Switzerland. The adoption of The Code as a recommendation, and not as a stronger regulation, was done to appease US opposition in particular, which financed $25 \%$ of the WHO's regular budget at the time. The US, under the newly elected Reagan administration, was the only member state to vote against The Code in May 1981 [28, 29, 44].

Delaying the extension of the recommended duration of exclusive breastfeeding

Opposing guidance on ending inappropriate promotion of foods for infants \& young children

Challenging the WHO initiative on conflicts of interest in nutrition

Codex Alimentarius Commission
Contesting revisions to Codex standards on infant, specialised and follow-up formulas
In 2000, the IFM (having since replaced ICIFI) unsuccessfully attempted to lobby WHO staff, to delay the adoption of new technical guidance and a WHA resolution planned for May that year, that would extend the recommended duration of exclusive breastfeeding from ' $4-6$ months' to 'about 6 months', and hence conceivably impact sales [44, 101]. This lobbying was coordinated across WHO's six regional committee meetings that year, and the Executive Board meeting and WHA the following year [101]

In 2016, IFM and ISDI issued a statement to the Executive Board to 'manufacture doubt' about new technical guidance clarifying The Code covered products marketed for ages 6-36 months, including follow-up and toddler milks, categories they considered outside of scope. Nestlé claimed because the final WHA Resolution 69.9 referred to the guidance as 'welcomed with appreciation' rather than 'adopted or approved', governments were not obligated to implement it [44, 102]. The resolution also called for an end to all forms of inappropriate promotion, as set out in the guidance, including cross-promotion. The International Dairy Foods Association (IDFA) endorsed the IFM and ISDI position, and engaged US officials to oppose the guidance, stating it was 'alarmed by the non-transparent, flawed process by which the WHO has developed this guidance' and called upon officials to 'work aggressively toward improving the WHO's processes and procedures to ensure the organization builds and maintains greater trust' [44].

In 2018, Trump Administration officials, aggressively opposed a new WHA resolution that included, among other provisions, the contested 2016 technical guidance. US Government delegates worked to water-down wording, questioned the supporting evidence, and threatened to remove military support and enact trade measures against Ecuador, the proponent of the resolution. This had a 'chilling' effect on others, with at least 10 member states declining to support the resolution, although it was eventually adopted by the WHA, through the leadership of Russia [44, 103].

In 2018, ISDI, the International Dairy Federation (IDF) and Global Dairy Platform, among others, provided submissions to a WHO consultation on a new tool for 'Safeguarding against possible conflicts of interest in nutrition programmes'. The ISDI submission argued that managing such conflicts was best left to country governments. The IDF submission called into question the consultation process itself, requesting a postponement and wider consultation [104].

Contestations of the Codex Standard for Infant Formula and Formulas for Special Medical Purposes Intended for Infants, have included how The Code is referenced in the Standard, whether in the main text or as a lesser footnote; allowable ingredients, and minimum and maximum nutrient ranges; and the allowable nitrogen conversion factor for determining 
Table 3 Actions by or on behalf of the baby food industry in relation to key multi-lateral organizations that govern the regulation of foods for infants and young children (Continued)

\begin{tabular}{ll}
\hline Targeted organization Objective (inferred) & Description \\
\hline & infant formula protein levels, with the IDF, supported by some dairy- \\
producing member states, advocating for a higher value than the one pro- & posed by leading expert groups [105, 106]. \\
& Contestations of the Codex Standard for Follow-Up Formula have included \\
the definition of products for ages 12-36 months, with pro-industry stake- & holders arguing these are not BMS; advocating the use of the term 'for- \\
mula' for products for young children, hence implying nutritional & adequacy; whether to reference The Code and resolutions (like WHA 69.9) \\
in the Preamble, with pro-industry stakeholders arguing sources 'external & to Codex' should not be referenced; that neither additives with sweet \\
& taste, types of sweeteners, or sugar content should be restricted in the \\
& Standard; and that 'cross-promotion' is not clearly defined and should be \\
excluded [105].
\end{tabular}

World Trade Countering country-level implementation of Organization The Code, and fostering regulatory chill
Between 1995 and 2019, there were 110 interventions a made in the WTO concerning existing or proposed BMS marketing, labelling or safety testing regulations of a member state. The majority of these interventions occurred in the TBT Committee, mainly concerning whether regulations were more restrictive than international standards (including Codex standards), and considered scientifically justified. Interventions also occurred during periodic trade policy reviews, where member state policies were assessed for compliance with WTO agreements. An even greater number of interventions occurred during the screening of new members for accession to the WTO, with the large majority of countries undergoing the accession process experiencing either exploratory questions and/or issue-specific negotiations (Initial Negotiation Rights) [Russ K, Baker P, Byrd M, Kang M, Siregar RN, Zahid H, McCoy D: Understanding the global trade and public health regime complex: a case study on breastfeeding and commercial breastmilk substitutes. Forthcoming].

Notes: $\mathrm{a}=$ here the term 'intervention' does not refer to trade arbitration; rather, it is defined as questions or comments relating to BMS regulations or proposed regulations in one member state, registered to a WTO committee or council, or raised during a trade policy review, by another member state [Russ K, Baker $\mathrm{P}$, Byrd M, Kang M, Siregar RN, Zahid H, McCoy D: Understanding the global trade and public health regime complex: a case study on breastfeeding and commercial breastmilk substitutes. Forthcoming]

notable examples of how Big Formula, and member states representing the industry, have lobbied to undermine the scope and strength of The Code, since it was first proposed in 1979. Article 19 of the WHO Constitution grants the World Health Assembly, as the world's highest health policy-making body, the power to adopt (listed from strongest to weakest) conventions, regulations and recommendations. As an example, the Framework Convention on Tobacco Control (FCTC) was adopted by the World Health Assembly in 2003, as a legally binding treaty. The adoption of The Code as a recommendation, rather than a more binding regulation, was attributed largely to the opposition of the US and other large-dairy producing member states at the time [27]. Since then, lobbying efforts have focused mainly on limiting the 'regulatory scope' of WHO technical guidance and subsequent WHA resolutions. This includes opposing the extension of the recommended duration of exclusive breastfeeding, and technical guidance concerning cross-promotion, and the designation of products for ages 6-36 months (i.e. follow-up and toddler milks) as BMS [44].

Big Formula and the baby food industry have also influenced standard-setting processes at CAC, the UN food standard-setting body jointly administered by
WHO and FAO, with a dual mandate to protect public health and safety, and to facilitate international food standards harmonisation and trade [30, 105, 107]. Codex standards - including specific 'commodity standards' for infant and specialised formulas, and follow-up formula, and 'general standards' on labelling, additives and others that apply to all commodities within scope - are developed by committees comprising voting member states, with technical input from observers, including industry trade associations and civil society organizations [105, 107]. Table 3 details several examples of how dairyproducing member states, and industry trade associations - mainly ISDI and the International Dairy Federation - have contested these standards.

This lobbying works in the interests of Big Formula and the wider industry for two key reasons. First, CAC standards function as a minimum benchmark, or regulatory 'floor', for the development of national regulatory measures on product composition, safety and labelling, and therefore influence regulatory standards worldwide $[30,107]$. Second, the CAC is explicitly referenced in the WTO's Sanitary and Phytosanitary Measures Agreement (SPS), and meets the criteria for a standard-setting body in the Technical Barriers to Trade Agreement (TBT). Subsequently, countries implementing regulatory 


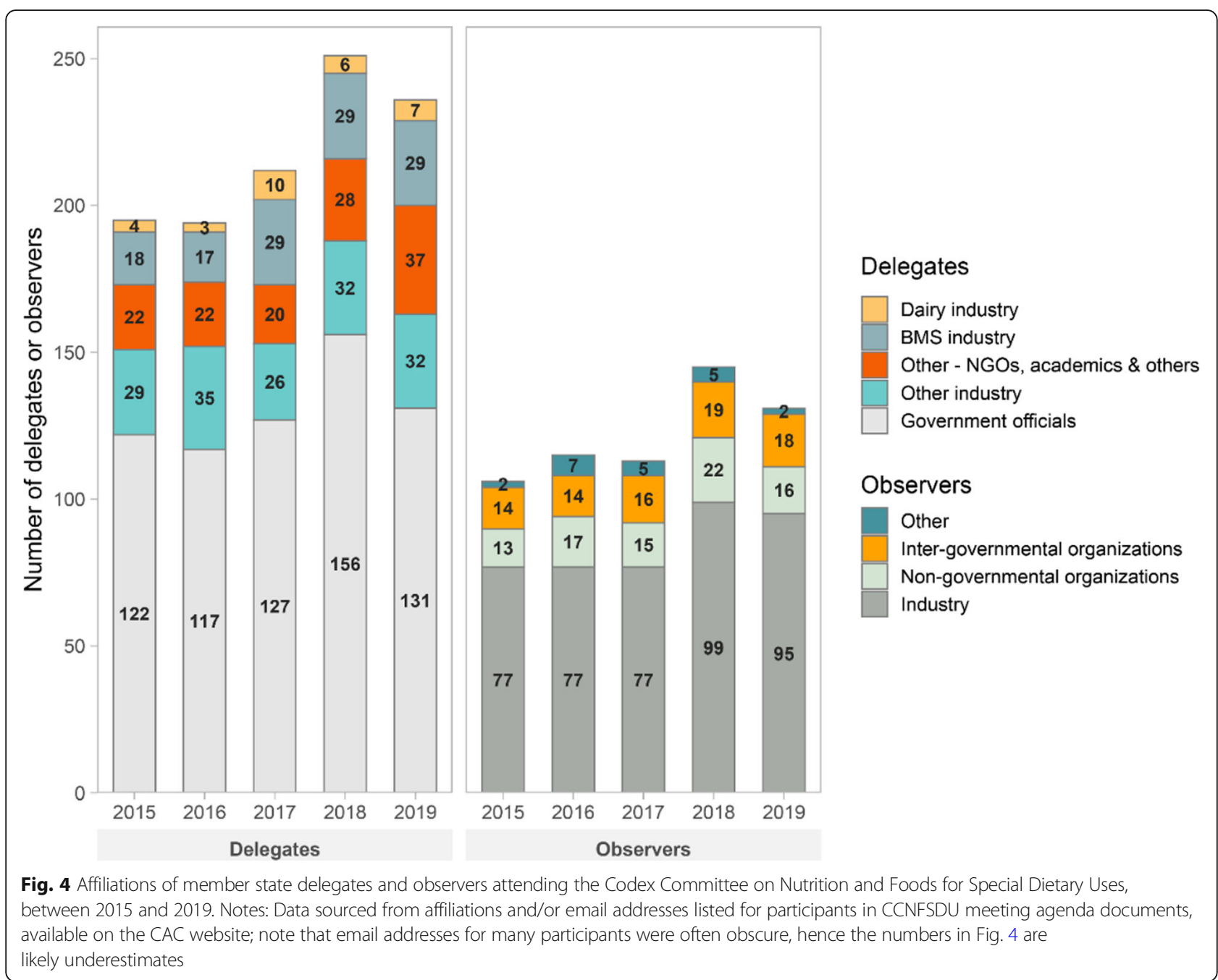

measures more stringent than Codex standards may be required to provide scientific justification in the WTO and other trade policy fora. Because of this, CAC standard-setting processes have become highly politicised, with strong industry participation and influence [30, 107].

In Fig. 4, we present new data on the affiliations of participants in the Codex Committee on Nutrition and Foods for Special Dietary Uses (CCNFSDU), mandated to develop the standards for infant and specialised formulas, and follow-up formula respectively. Between 2005 and 2019, industry not only comprised 70\% of non-state observers participating in the CCNFSDU meetings, far out-numbering observers from civil society and inter-governmental organizations, but also $28 \%$ of member state delegations. In several instances industry representatives were the member state delegation in its entirety.

The influence of the baby food industry is also evident in the WTO, the inter-governmental organization for developing, maintaining and enforcing a global system of trade rules and agreements. As WHO and UNICEF recently reported, formal trade arbitration concerning national implementation of The Code (i.e. through a WTO dispute panel and settlement process) has yet to eventuate [108]. However, we have shown how member states with large dairy-producing industries - especially the US, EU, Australia and New Zealand - frequently use WTO processes to challenge BMS-related regulations adopted by other member states [Russ K, Baker P, Byrd M, Kang M, Siregar RN, Zahid H, McCoy D: Understanding the global trade and public health regime complex: a case study on breastfeeding and commercial breastmilk substitutes. Forthcoming]. Between 1995 and 2019, 110 interventions occurred against WTO member states relating to actual or proposed BMS marketing, labelling or safety testing regulations (Table 3). Here the term 'intervention' refers to 'questions or comments relating to restrictions or proposed restrictions in one member country, registered to a WTO committee or council, by a delegation from another 
country, or during a trade policy review'. In some instances, interventions occurred across several years, resulting in significant changes to the planned implementation of The Code by a member state. For example, between 2015 and 2018, when Thailand started revising its 'Milk Code', including extending the scope of products from the ages $0-12$ to -36 months, it faced repeated interventions via the WTO Trade Policy Review process, and then in the TBT Committee. The National Assembly passed the final legislation, but without the proposed restrictions on the marketing of products for ages 12-36 months [Russ K, Baker P, Byrd M, Kang M, Siregar RN, Zahid H, McCoy D: Understanding the global trade and public health regime complex: a case study on breastfeeding and commercial breastmilk substitutes. Forthcoming].

\section{Contesting standards in bi-lateral and national policy- making arenas}

The baby food industry spend large sums on lobbying and political financing to influence government positions in the above international arenas, and to achieve favourable regulatory environments within countries. Several examples of this lobbying in national arenas, and also bilateral actions taken by governments against other governments on behalf of the industry, are listed in Table 4. Although Nestlé, Danone, RBMJ and Abbott all have corporate policies on lobbying, framed as 'interactions with public authorities', 'advocacy' or 'political participation' in Table 5 respectively, much of their lobbying is conducted by the aforementioned trade associations.

To illustrate this further, and to demonstrate links between lobbying actions in both the national and international arenas, we present US lobbying data. We have already shown how the US has had a disproportionate impact in opposing strong international standards on foods for infants and young children. This influence is understandable given that, between 2007 and 2018, the six US market-leading corporations together spent US\$184.2 million in total, on lobbying the US Government [67]. This lobbying was targeted mainly at the Senate, the House of Representatives, and at various times, the Food and Drug Administration, State Department, Office of the US Trade Representative (USTR), and Department of Agriculture (USDA). As Fig. 5 shows, four of these corporations declared lobbying expenditures as specifically related to BMS, totalling US\$55.1 million (30\% of total lobbying expenditure) or an average of US\$5 million per year, with the number of lobbyist they employed fluctuating between 20 and 80 over the time period. Of this BMS-related expenditure, US\$43.8 million (79.4\%) was attributed to Abbott alone, and US10.1 million (18.4\%) to Mead Johnson (all reported prior to its acquisition by Reckitt Benckiser in 2017) [67].
Significant BMS-related lobbying expenditures were also reported by dairy trade associations, food and beverage trade associations, and the Infant Nutrition Council of America [Russ K, Baker P, Byrd M, Kang M, Siregar RN, Zahid H, McCoy D: Understanding the global trade and public health regime complex: a case study on breastfeeding and commercial breastmilk substitutes. Forthcoming].

Of Abbott's expenditure on BMS-related lobbying, US\$20.0 million (45.8\%), was dedicated to trade-related concerns. For Mead Johnson, this figure was US $\$ 5.8$ million (57.2\%) [67]. This lobbying was frequently targeted at the State Department and USTR, and to significant effect. As detailed in Table 4, this was reflected in actions taken by the US Government on behalf of the industry to oppose marketing regulations in Hong Kong, Thailand, Malaysia and Indonesia in the WTO, and/or through direct bilateral engagement with governments in national arenas $[116,119]$. Lobbying targeted at the USDA was also significant, conceivably because this agency administers the nation's Special Supplemental Programme for Women, Infants and Children (WIC). Through WIC, the government purchases more than half of all milk formula sold in the US market, and provides 'nutrition services' to $\sim 1.9$ million infants [23, 124 , 125]. In 2014, Nestlé alone spent an estimated US $\$ 160$, 000 lobbying in relation to the WIC programme [43].

Political financing is the deployment of financial resources for political gain, in particular payments, gifts or promises, made to elected officials, political parties or government administrators. Big Formula's corporate policies on political financing vary (Table 5). Danone and RBMJ do not allow it, Nestlé allows it with executive permission, and Abbott (US) allows it. We were unable to source a policy for RFC. However, none of those with policies appear to have prohibited political financing by third parties. Total political financing by the lead US corporations averaged $\sim$ US $\$ 2$ million per year between 1990 and 1999, increasing to US\$3 million per year between 2000 and 2012, and have averaged \$1 million per year since then. More funds went to candidates for the House of Representatives than for the Senate or White House, and most recipients won their election. In the last 10 years, Abbott's contributions have steadily grown and now dominate industry political contributions. Political financing also occurs at sub-national levels. Abbott for example, donated \$US2.9 million between 2009 and 2019 to state-level candidates and political action committees [126].

\section{Policy substitution \& partnership}

The power of Big Formula over first-food systems further resides in the adoption of voluntary self-regulation through corporate policies on responsible marketing, 
Table 4 Political actions by or on behalf of baby food industry in bilateral and national policy-making arenas

\begin{tabular}{ll}
\hline Country & Objective (inferred) \\
\hline Canada & $\begin{array}{l}\text { Lobbying to influence a free trade agreement to } \\
\text { resolve a non-tariff barrier to trade issue }\end{array}$
\end{tabular}

China Delaying the introduction of new food safety regulations

Guatemala Challenging new labelling provisions

Hong

Kong Preventing the expanded scope of marketing
regulations

\section{Description}

Canada is the leading market for US processed dairy exports. In 2017, facing a

surplus supply of skim milk, Canada implemented a new 'Class 7' milk price, making domestic products cheaper, and thereby increasing Canadian exports of skim milk powder, while making dairy product imports (including infant formula) from the US less competitive [109]. Between 2016 and 2019, this provoked US\$6, 184,614 in lobbying the US Government, by infant formula producers and dairy industry associations [67]. The US raised concerns with Canada bilaterally and in the WTO Committee on Agriculture. Eventually, it was agreed to eliminate the Class 7 price under the new US-Mexico-Canada Agreement (USMCA), signed in 2018. In addition, Canada was required to monitor its exports of skim milk powder and infant formula, impose a surcharge on exports exceeding thresholds specified in the USMCA, and expand its duty-free tariff rate quotas on US dairy imports [109]. [Russ K, Baker P, Byrd M, Kang M, Siregar RN, Zahid H, McCoy D: Understanding the global trade and public health regime complex: a case study on breastfeeding and commercial breastmilk substitutes. Forthcoming]

China strengthened food standards through a new Food Safety Law in October 2015. This included stricter product safety regulations, harsher punishments for violators, strengthened accountability mechanisms including protections for whistle-blowers, product certification requirements, and new provisions for infant formula products [110, 111]. Between 2013 and 2016, the National Milk Producers Federation, Mead Johnson, Abbott, and Infant Nutrition Council of America spent US\$1,255,577 on lobbying the US Government on this issue [67]. The US Government submitted comprehensive written comments on the draft measure, and also urged China to notify the draft measure to the WTO TBT Committee, and the WTO SPS Committee. Implementation of the new product certification requirement was delayed by 2 years [112]. [Russ K, Baker P, Byrd M, Kang M, Siregar RN, Zahid H, McCoy D: Understanding the global trade and public health regime complex: a case study on breastfeeding and commercial breastmilk substitutes. Forthcoming]

In 1983, Guatemala was among the first countries to implement The Code into national law. The Guatemalan Law on the Marketing of Breastmilk Substitutes Decree 66-83, and Government Agreement NO 841-87, mandated that all products must state breastmilk is the best food for children under 2 years of age, and prohibited the idealisation of formula through the use of pictures of infants. In 1992, the Gerber Company, which used a picture of the 'Gerber Baby' face trademark on its products, refused to comply with a request by the Food and Drug Registration and Control Division to comply with the law. Gerber requested a court injunction, claiming its products were out of scope, and that this violated intellectual property rights obligations under international trade law. Gerber engaged the US State Department to apply pressure on the Guatemalan Government to amend the labelling provisions under the law, threatening to remove Guatemala's 'Most Favoured Nation' status under the US Generalized System of Preferences. In 1995, Guatemala's Supreme Court of Justice ruled in favour of Gerber, arguing the law applied to locally produced products only, and not imported ones [27, 113].

In 2012, the Hong Kong Infant and Young Child Nutrition Association, a trade association representing Abbott, Danone, RFC, Mead Johnson, and Nestlé, opposed a draft regulation that would ban the promotion of foods for children aged 0-36 months. A document was presented to legislators stating the legislation should follow The Code, and apply to products for 0-6 months only. It stated 'There is no scientific evidence to show promotion of food for children 6 months or above has affected the breastfeeding rates and its duration... Any biased overregulation in infant formula marketing will be contrary to Hong Kong's open free market economy and...the fundamental right of consumers to information and choices.' [114]. An extensive legal analysis was published, concluding the draft regulation violated the WTO's TBT, SPS and TRIPS Agreements [115]. The US Trade Representative, in its 2017 report on foreign barriers to trade, stated 'If the draft Code is implemented as originally drafted, U.S. stakeholders maintain that, together with related legislative proposals, it will have significant negative impacts on sales of food products for infants and young children, and is more restrictive than relevant international standards'. Furthermore, 'The United States is continuing to engage with the Hong Kong government on this draft measure' [116].

In 2003, the Government of India strengthened its Infant Milk Substitutes, Feeding Bottles, and Infant Foods (IMS) Act, so that it bans the marketing of food for children up to 24 months of age, as well as marketing by BMS producers to medical professionals and organizations, enforceable with criminal penalties [117]. In 2009, the Government further revised its certification compliance list, which 
Table 4 Political actions by or on behalf of baby food industry in bilateral and national policy-making arenas (Continued)

\section{Country Objective (inferred)}

Indonesia Requesting notification of new regulations to the WTO

Challenging under fill of import quotas in the WTO, and lobbying for enhanced market access

\section{Malaysia Opposing proposed marketing regulations}

Philippines Weakening the country's Milk Code and implementing regulations

Thailand Preventing the expanded scope of marketing regulations

\section{Description}

includes infant formula. Products on the list must be certified for safety by the Bureau of Indian Standards [118]. Between 2012 and 2014, Mead Johnson, Abbott, and National Milk Producers Federation spent US\$2,435,240 lobbying the US Government on this 'Indian Bureau of Standards regulatory issue' [67]. [Russ K, Baker P, Byrd M, Kang M, Siregar RN, Zahid H, McCoy D: Understanding the global trade and public health regime complex: a case study on breastfeeding and commercial breastmilk substitutes. Forthcoming]

In 2016, Indonesia's food and drug regulatory agency, Badan Pengawas Obat dan Makanan (the National Agency of Drug and Food Control), issued a draft of the Government Regulation Concerning the Labelling and Advertisement of Food, to implement provisions of the Food Law No.18/2012. The draft regulation would prohibit advertising or promotion of milk products for children aged 0-2 years, and the use of claims on foods for children aged 0-3 years; it would 'severely restrict the infant formula industry's interactions with health care providers', and included further stringent requirements for nutrition labelling. The US Government requested Indonesia notify the measure to the WTO TBT Committee, before finalizing the regulation [119].

Between 1996 and 2017, WTO members continuously raised concerns about Japan's under fill of tariff rate quotas (TRQ) on dairy products, including infant formula. In 2015, the US released a press release on the impacts of the concluded negotiations on the Trans-Pacific Partnership Agreement, focusing on agricultural trade with Japan. This said that Japan would establish a transitional country specific quota (CSQ) for US exports of mineral concentrated whey, prepared infant formula, and whey. Between 2013 and 2014, prior to the conclusion of negotiations, dairy industry associations spent US\$451,000 lobbying the US Government in relation to the dairy specific aspects of the TPP, mentioning Japan [67]. [Russ K, Baker P, Byrd M, Kang M, Siregar RN, Zahid H, McCoy D: Understanding the global trade and public health regime complex: a case study on breastfeeding and commercial breastmilk substitutes. Forthcoming]

In 2014, the Ministry of Health started revising and expanding Malaysia's existing 'Code of Ethics' on the Marketing of Infant Foods and Related Products. This included expanded restrictions on educational, promotional, and marketing practices for infant formula and products for young children, as well as on the use of symbols and trademarked brand names on labels or packaging $[116,119]$. The US Government raised questions concerning the evidence used in developing the proposed measure [116].

In 2006, the Pharmaceutical \& Healthcare Association of the Philippines representing US milk formula manufacturers, and the US Chamber of Commerce (USCC), unsuccessfully appealed to the Supreme Court of the Philippines to rescind new Implementing Rules \& Regulations (IRR) of the 1986 Milk Code. The new IRRs would extend products covered to 0-24 months, and ban false health and nutrition claims. The USCC sent a letter to the President of the Philippines, claiming the 'the country's reputation as a stable and viable destination for investments is at risk'. Industry lobbyists attempted to transfer the legislative debate in the House of Representatives from the Committee on Health, to the Committee on Trade and Industry, aiming to have the IRRs declared void [120]. In 2012, the Infant and Paediatric Nutrition Association of the Philippines, representing a wider number of corporations, supported a new 'Milk Monster' bill that would, among other things, reduce coverage of marketing restrictions to products for ages 0-6 months [120].

In 2015, Thailand began drafting a revised version of its 'Milk Code', the Marketing Control of Foods for Infants and Young Children and Related Products. This would restrict educational, promotional, and marketing activities, including the use of trademarked brand names, packaging, and symbols, establish stronger penalties for advertising violations, and expand coverage to products for children aged 0 36 months. The US Government made 'repeated requests' that Thailand notify this measure to the WTO, which it did in November 2016. In April 2017, the National Legislative Assembly passed revisions to the Milk Code. Although various marketing restrictions, as well as penalties for violations were retained, advertising restrictions for products for ages 12-36 months were removed [119]. In 2017, the US Government reported it was 'seeking to ensure that Thailand's final measure 'takes into account appropriate scientific and technical information in order to avoid any unnecessary restrictions on trade', and that it had engaged 'extensively with Thailand' throughout the period 'both bilaterally and at the WTO and continues to monitor developments, particularly any potential regulations relating 
Table 4 Political actions by or on behalf of baby food industry in bilateral and national policy-making arenas (Continued)

\begin{tabular}{ll}
\hline Country & Objective (inferred) \\
\hline $\begin{array}{l}\text { United } \\
\text { States }\end{array} \quad \begin{array}{l}\text { Lobbying to influence key government } \\
\text { programmes and policies }\end{array}$
\end{tabular}

States programmes and policies

Vietnam Preventing the expanded scope of marketing regulations

\section{Description}

to restrictions on products for young children' [119].

Extensive political activities by Nestlé in the US have been documented [43]. In 2014, Nestlé spent an estimated US\$160,000 lobbying in relation to the Special Supplemental Nutrition Program for Women, Infants, and Children (WIC) programme, which provisions free formula for low-income families, and for which companies 'bid' to secure preferred provider status in state-level contracts, with bids often at or below cost [43]. In 2015, Mead Johnson called for narrowing the eligibility rules of the WIC programme [121]. Mead Johnson, Nestlé, and dairy company executives, served on the US Dietary Guidelines Advisory Committee [122].

In 2012, the US Embassy in Hanoi unsuccessfully petitioned the Chairman of Vietnam's National Assembly and other senior ministers, to prevent expanded marketing restrictions for products for ages 0-6 moths to $0-24$ months [120]. The letter stated 'several US companies have contacted the US Embassy regarding their serious concerns about this proposed prohibition ... which could have a significant negative impact on their business in Vietnam. We share their concerns', Further, 'We have not seen any compelling scientific, legal, or economic argument for changing the current regulatory regime' [123].

Notes: Lobbying data reported in relation to Canada, China, India and Japan were sourced from the Centre for Responsive Politics

and the acceptance and legitimisation of these private regulatory initiatives by third parties. These policies are summarised in Table 5.

The first explicit promotion of self-regulation began in 1975, when ICIFI released a Code of Ethics as a public relations response to the severe public scrutiny Nestlés was receiving at the time. The IFM had an industry-wide self-regulatory code, the Rules of Responsible Conduct, until it was disbanded in 2016 [127]. At the country- level, several self-regulatory or co-regulatory codes exist. For example, the Marketing in Australia of Infant Formulas: Manufacturers and Importers Agreement, administered by the Infant Nutrition Council Australia and New Zealand, a trade association representing Big Formula, functions as Australia's 'national response' to The Code. However since 2016, there appears to be no global industry-wide policy. Instead, various policies are adopted across the corporations. Nestlé first adopted

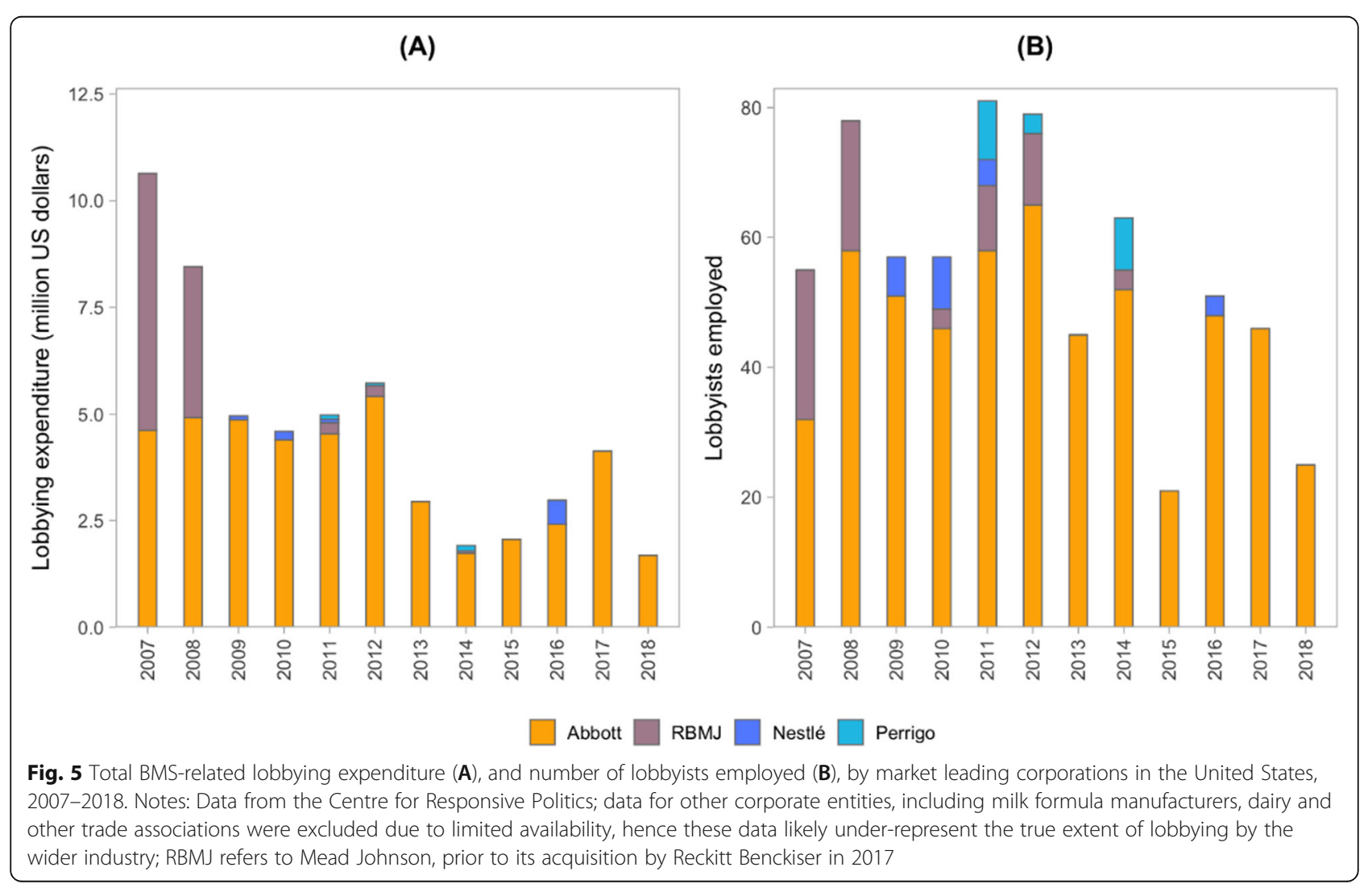


Table 5 Corporate policies (voluntary self-regulation) adopted by Big Formula on marketing, lobbying and political financing

\begin{tabular}{|c|c|c|c|c|c|}
\hline Corporation & Nestlé & Danone & RBMJ & Abbott & RFC \\
\hline $\begin{array}{l}\text { Policy name } \\
\text { (date of latest } \\
\text { version) }\end{array}$ & $\begin{array}{l}\text { Policy and Procedures for } \\
\text { the Implementation of the } \\
\text { WHO International Code of } \\
\text { Marketing of Breast-Milk Sub- } \\
\text { stitutes (2017) }\end{array}$ & $\begin{array}{l}\text { Policy for the } \\
\text { marketing of breast- } \\
\text { milk substitutes; Proce- } \\
\text { dures manual (2018) }\end{array}$ & $\begin{array}{l}\text { Infant \& Child Nutrition } \\
\text { Pledge; Policy and } \\
\text { Procedures on the } \\
\text { Marketing of Breast-Milk } \\
\text { Substitutes (2018) }\end{array}$ & $\begin{array}{l}\text { Policy on the } \\
\text { marketing of infant } \\
\text { formula - global } \\
\text { policy (2017) }\end{array}$ & $\begin{array}{l}\text { Corporate Policy for the } \\
\text { Marketing of Infant Foods; } \\
\text { Corporate Standard for } \\
\text { the Marketing of Infant } \\
\text { Foods (2017) }\end{array}$ \\
\hline $\begin{array}{l}\text { Year of first } \\
\text { corporate } \\
\text { policy } \\
\text { (revisions) }\end{array}$ & $\begin{array}{l}1982 \\
(1996,2004,2010,2017)\end{array}$ & $\begin{array}{l}2011 \\
(2012,2013,2016, \\
2018)\end{array}$ & $\begin{array}{l}2017 \\
\text { (IFM's policy before this) }\end{array}$ & $\begin{array}{l}2016 \\
\text { (IFM's policy before } \\
\text { this) }\end{array}$ & - \\
\hline $\begin{array}{l}\text { Compliance } \\
\text { with The } \\
\text { Code } 2018 \\
\text { (2016); ATNI } \\
\text { score (\#rank) }\end{array}$ & $\begin{array}{l}45 \%(36 \%) \\
\# 2\end{array}$ & $\begin{array}{l}46 \%(31 \%) \\
\# 1\end{array}$ & $\begin{array}{l}10 \%(5 \%) \\
\# 5\end{array}$ & $\begin{array}{l}34 \%(7 \%) \\
\# 3\end{array}$ & $\begin{array}{l}25 \%(24 \%) \\
\# 4\end{array}$ \\
\hline $\begin{array}{l}\text { General } \\
\text { compliance } \\
\text { statement }\end{array}$ & $\begin{array}{l}\text { Corporate policy, or national } \\
\text { regulations, whichever } \\
\text { stricter }\end{array}$ & $\begin{array}{l}\text { Corporate policy, or } \\
\text { national regulations, } \\
\text { whichever stricter }\end{array}$ & $\begin{array}{l}\text { Corporate policy, or } \\
\text { national regulations, } \\
\text { whichever stricter }\end{array}$ & $\begin{array}{l}\text { Corporate policy, } \\
\text { or national } \\
\text { regulations, } \\
\text { whichever stricter }\end{array}$ & $\begin{array}{l}\text { Corporate policy, or } \\
\text { national regulations, } \\
\text { whichever stricter }\end{array}$ \\
\hline $\begin{array}{l}\text { Scope of } \\
\text { countries } \\
\text { included }\end{array}$ & 'Higher-risk countries' only ${ }^{a}$ & $\begin{array}{l}\text { Worldwide and } \\
\text { 'Higher-risk countries'a }\end{array}$ & 'Higher-risk countries' only ${ }^{a}$ & $\begin{array}{l}\text { Worldwide and } \\
\text { 'Higher-risk } \\
\text { countries's }^{\text {(3 }}\end{array}$ & Worldwide \\
\hline $\begin{array}{l}\text { Products } \\
\text { covered } \\
\text { worldwide in } \\
\text { corporate } \\
\text { policy }\end{array}$ & - & $\begin{array}{l}\text { Standard formula (0-6 } \\
\text { m); any other BMS (0- } \\
6 \text { m); delivery } \\
\text { products; excludes } \\
\text { specialised formulas }\end{array}$ & - & $\begin{array}{l}\text { Standard formula } \\
(0-6 \mathrm{~m}) \text {; any other } \\
\text { BMS, including } \\
\text { complementary } \\
\text { foods (0-6 m) }\end{array}$ & $\begin{array}{l}\text { Standard, follow-up and } \\
\text { special formulas (0-12 m); } \\
\text { some products with same } \\
\text { brand name / logo }\end{array}$ \\
\hline $\begin{array}{l}\text { Products also } \\
\text { covered in } \\
\text { 'higher-risk' } \\
\text { countries }^{a}\end{array}$ & $\begin{array}{l}\text { Standard \& follow-up formula } \\
(0-12 \mathrm{~m}) \text {; certain specialised } \\
\text { formulas; bottles and teats }\end{array}$ & $\begin{array}{l}\text { Follow-up formula (6- } \\
12 \mathrm{~m}) \text {; complementary } \\
\text { foods \& drinks (0-6 m) }\end{array}$ & $\begin{array}{l}\text { Standard \& follow-up for- } \\
\text { mula (0-12 m); delivery } \\
\text { products; complementary } \\
\text { foods ( } 0-6 \text { m); excludes spe- } \\
\text { cialised formulas }\end{array}$ & $\begin{array}{l}\text { Standard \& follow- } \\
\text { up formula }(0-12 \\
\text { m); bottles and } \\
\text { teats }(0-12 \mathrm{~m})\end{array}$ & - \\
\hline $\begin{array}{l}\text { Corporate } \\
\text { third-party } \\
\text { auditors listed } \\
\text { on website }\end{array}$ & $\begin{array}{l}\text { FTSE4Good since } 2011 \text { (PWC } \\
\text { audits every } 18 \text { months); } \\
\text { Bureau Veritas (audits } 3 \\
\text { countries / year); ATNI }\end{array}$ & $\begin{array}{l}\text { FTSE4Good since } 2016 \\
\text { (PWC audits every } 18 \\
\text { months); ATNl; others }\end{array}$ & ATNI & ATNI & ATNI \\
\hline $\begin{array}{l}\text { Policy on } \\
\text { corporate } \\
\text { lobbying }\end{array}$ & $\begin{array}{l}\text { Policy on Transparent } \\
\text { Interactions with Public } \\
\text { Authorities }\end{array}$ & $\begin{array}{l}\text { Global Advocacy } \\
\text { Policy } 2017\end{array}$ & $\begin{array}{l}\text { Global Responsible } \\
\text { Advocacy Policy }\end{array}$ & $\begin{array}{l}\text { Corporate political } \\
\text { participation }\end{array}$ & - \\
\hline $\begin{array}{l}\text { Policy on } \\
\text { political } \\
\text { financing }\end{array}$ & $\begin{array}{l}\text { Allowed with executive } \\
\text { permission; allowed by third } \\
\text { parties }\end{array}$ & $\begin{array}{l}\text { Not allowed; allowed } \\
\text { by third parties }\end{array}$ & $\begin{array}{l}\text { Not allowed; allowed by } \\
\text { third parties }\end{array}$ & $\begin{array}{l}\text { Allowed (US); } \\
\text { allowed by third } \\
\text { parties }\end{array}$ & - \\
\hline
\end{tabular}

Notes: Data sourced from company websites and reports; $a$ = countries are classed as 'higher-risk countries' by the FTSE4Good Breast Milk Substitutes Marketing Criteria when having high rates of mortality (> 10 per 1000) or acute malnutrition $(>2 \%)$ in children aged under five; $\beta=$ for Abbott 'higher-risk countries' are defined, although without clarification, by reference to the Global Nutrition Report 2016; Nestlé also has a Code of Interaction with Healthcare Professionals and Institutions for Nestlé Nutrition Business Units, and a Standard for Donations or Low-Cost Supplies for use in Emergencies and for Social Purposes; the others include these in their overarching policies. FTSE4Good commissions Pricewaterhouse Coopers to verify BMS marketing practices against 104 criteria in higher-risk countries. Corporate policies apply to employees of each corporation, and third parties including agents, distributors and other partners. The policies listed in this table only represent corporate policies on BMS; similar policies also exist for several otherenvironmental, social and governance (ESG) issues

such a policy, the Nestlé Charter, in 1982 [128]. Others followed only much later; Danone in 2011, Abbott in 2016, and RBMJ and RFC in 2017. However, these policies fall far short of compliance with The Code, ranging from 46 to $10 \%$, as assessed by the Access to Nutrition Initiative in 2016-18 [129].

In their policies, all state they abide by The Code as implemented by national governments - i.e. as adopted into national laws and regulations - notwithstanding that, through their aforementioned trade associations, they lobby against those very laws and regulations in the first place. The Code applies to all countries, irrespective of their development status. Yet most corporate policies are bifurcated, with stricter standards for 'higher-risk' countries with high child malnutrition and mortality rates; the policies of Nestlé and RBMJ only apply to such countries. None apply to products for children beyond 12 months of age, nor address the issue of crosspromotion (see the later section on marketing strategies) [129]. At the country-level, subsidiary and affiliate firms 
often fail to comply with both national regulations and corporate policies [129]. Since 1991, IBFAN [130], and several others [39, 131, 132], have reported extensive Code violations across many countries. These reports are often reviewed and contested by the companies, who consider compliance with local laws and regulations, or their corporate policies only, and not with The Code itself [133].

Big Formula seeks to legitimise their corporate policies, and reinforce their image as socially responsible actors, through ostensibly independent third-party corporate accountability initiatives. Nestlé first initiated this strategy in 1982, when it established the Nestlé Infant Formula Audit Commission (NIFAC), to monitor compliance with its stated commitments in the Nestlé Charter. The over-arching objective was to end Nestlés longrunning conflict with activists, co-opt more moderate groups, and thereby 'divide and conquer'. It was to serve as 'an instrument for damage control and containment', by re-focusing media attention away from the activists case, and establishing 'boundaries around the issues that activists might raise, and the manner in which they were addressed' [134]. Considered an important public relations victory, this contributed to some (although not all) civil society groups ending the Nestlé Boycott in 1984. However, NIFAC was soon considered 'seriously inadequate' [98], when continuing country-level violations were reported, and it was disbanded in 1991 [128]. Today, all except Abbott detail internal auditing and compliance processes for their policies, although RFC does so vaguely. Nestlé and Danone also list third-party auditors, of which two are most apparent - the Access to Nutrition Initiative (ATNI), and the FTSE4Good Index as an ethical investment index of the UK company FTSE Russel.

Nestle was the first to join the FTSE4Good Index in 2011, by meeting its 'Breast Milk Substitutes Marketing Criteria' (from hereon 'Criteria'). In order to join, company policies must 'align' with The Code, and comply with national legislation and regulatory requirements. Danone followed in 2016, and then Mead Johnson in 2018, following its acquisition (and subsequent policy revisions) by the existing member Reckitt Benckiser [44]. Other companies, however, have viewed the Criteria as unrealistic 'because it limits their ability to market' [135]. The Criteria also falls well short of compliance with The Code. Initially launched in 2001, the Index excluded any company allegedly breaching The Code, and hence no companies were included. The Criteria were revised in 2003, although again no company met the entry requirements. In 2011, it was further revised, this time through a process managed by a small group of industry experts and academics, enabling Nestlé's entry into the Index. The criteria deals with some issues outside the scope of The Code, for example, by requiring disclosures on corporate lobbying practices and internal compliance systems. However, the new criteria required 'alignment' and not compliance with The Code, and as 'a start' applied to 'higher risk' countries only, which reflected the design of Nestle's own policy [135].

Although, some corporations state their policies are not intended as interpretations nor replacements of The Code, Nestlé has represented the FTSE4Good BMS Criteria as an acceptable level of regulation. For instance, in 2017 the company stated 'More than 35 years after its adoption, only 39 countries have implemented all the recommendations of the WHO Code. To rapidly accelerate progress, all countries that are yet to do so could pass regulations aligned with the minimum standards set by the [Criteria] ...' [136]. However, this would fall far short of full implementation of The Code. Such policies, and third-party auditing reports, are also used directly in public communications to portray Big Formula as compliant. For instance, after ranking second place in the 2018 ATNI assessment, and despite scoring just 45\%, a Nestlé press release claimed this reflected it's 'commitment to policies, practices and compliance' with The Code [137]. Earlier, in 2014, the Chairman of Nestlé was quoted as saying 'We are the only infant formula producer which is part of FTSE4Good. We are being checked and controlled by FTSE4Good. They make their audits in different parts of the world and we have to prove that we are complying with the WHO Code and up to now we can prove that in everything we are' [138], as quoted in [96].

Despite their violations of The Code, Big Formula's 'social license' to operate under this self-regulatory regime, is further legitimised through partnerships with UN initiatives and agencies. For example, in 2002, Nestlé joined the UN's Global Compact 'without challenge', as arguably the world's largest self-regulatory initiative, that pledges corporations to abide by ten principles on labour standards, human rights and environmental sustainability [31, 44]. In 2019, Danone partnered with the Food and Agricultural Organization of the United Nations to promote nutrition, food safety and sustainable food systems [139].

\section{Strategic corporate philanthropy}

Another important example of Big Formula's power is strategic corporate philanthropy, involving the establishment of tax-exempt corporate foundations, as outlined in Table 5, that fund a range of social and environmental initiatives. These further foster an image of corporate social responsibility, and serve directly as a form of promotion.

For example, the Abbott Fund, established in 1951, involves a range of partnerships and funding arrangements to lead change and create new models for health care systems, improve nutrition and address other social 
needs', including various child nutrition and micronutrient initiatives across several countries [140]. Since 2012, the Danone Ecosystem Fund has supported the Srikandi Academy, a training institute in Indonesia, through its domestic brand Sari Husada in partnership with the local organization PKPU. By working with key health professional associations, this aims to develop a Ministry of Health endorsed first 1000 days curriculum and toolkits for 'upskilling' Indonesia midwives and health workers, with further business coaching, microcredit and medical equipment made available for establishing practices in rural areas. Through this programme Sari Husada contacts 80,000 midwives each year. As of 2016, it had trained 228 'health care cadres' to engage midwives and spread awareness to mothers, and had sensitised 47,893 people in rural areas to nutrition [141].

Corporate philanthropy also results in direct brand promotion through the donation of surplus products during emergencies, often to humanitarian relief organizations, and well in excess of actual need [142]. In 2000, for example, Wyeth and Nestlé were quoted in a Wall Street Journal article as ready to donate tonnes of free formula for HIV-infected mothers in Sub-Saharan Africa, if asked to by UNICEF. The article framed UNICEF's refusal to accept these donations as representing a 'feud against the industry' and as 'killing millions of children' [101]. In 2017, in just one month, Mead Johnson donated enough milk formula for $\sim 54,000$ child feedings across three US states and territories affected by natural disasters [143].

The Covid-19 pandemic has also been utilised as a marketing opportunity, under the guise of corporate social responsibility. For example, in the Philippines since the beginning of the pandemic (January 2019 to July 2020), there were 291 reported violations of the countries 'Milk Code' legislation, compared with 70 in 2019. Of these violations, 235 (81\%) were related to donations of BMS products [144]. Covid-19 related marketing violations were reported in Canada, Italy, India, Pakistan, the Philippines and the UK [145]. This included, for example, inferring products boost immunity, associating products with health authorities, offering counselling and support services to parents, and sponsoring health professional 'educational' events on Covid-19 and infant and young child feeding [144].

\section{Co-opting health professionals}

The co-option of healthcare professionals in the marketing of their products is a further representation of Big Formula's power, despite strict provisions in The Code against such practices [33]. A 'comfortable symbiotic relationship' between physicians and formula companies has long existed, ever since Henri Nestlé first pioneered the industry's medicalised marketing techniques in the late nineteenth Century [73], and prescribing formula became a lucrative practice for both. Marketing to health professionals led to formula becoming widely available and used in hospitals throughout the mid-twentieth century in many countries, and both doctors and the public coming to perceive formula as convenient, safe and medically-endorsed, and as associated with modernity and 'scientific motherhood' [70-72].

Paediatricians, allergists, nurses, midwives, dietitians, lactation consultants and nutritionists, are among others, trusted sources of infant and young child feeding advice for parents. Medical endorsement bolsters Big Formula's legitimacy with consumers and policy-makers, and serves as an important form of promotion in itself. A significant proportion of their sales workforce is dedicated to 'securing the recommendation'. For example, Mead Johnson (now RBMJ) had a global salesforce of 1900 employees in 2010, of which 1350 (71\%) were dedicated to health care settings, and the remaining 550 (29\%) to pharmacy and supermarket retailers [21]. Techniques used across the industry have included site visits to hospitals, sponsoring new clinical equipment and the design of newly constructed neonatal wards, providing free or low-cost samples for use in maternity discharge packs, providing branded gifts (e.g. lanyards, mugs and pens), paid advertising in journals, various 'educational interfaces', and sponsoring professional associations and emerging professional influencers $[37,146]$. Some have acted illegally. For example, sales staff at Danone's subsidiary Dumex, in China, were found to have bribed at least 116 people from across 85 hospitals and health groups, to promote products to parents of newborns [147].

Educational interfaces have included the sponsorship of scientific meetings (e.g. seminars, symposia and conferences), and direct provision of continuing education courses for health workers, delivered on-site and often with meals and refreshments [146], or through extensive online 'e-learning' platforms. For example, the latter includes the Nestlé Nutrition Institute, a not-for-profit organization providing 300,000 health professional members worldwide with access to 3000 articles, hundreds of videos, infographics and presentation slides, described as an 'exclusive accredited e-learning and continuous medical education programs that provide practical guidance on the nutrition of infants and children' $[148,149]$. In some instances, they have partnered with training providers directly. For example, since 2017, Abbott partnered with teaching hospitals in China and Vietnam, to train $>6500$ healthcare professionals, providing 'a model for other hospital pediatric nutrition programs in the region' [150].

Sponsoring professional associations is widely practiced. A 2019 survey of 114 paediatric association 
websites found $60 \%$ received financial support from BMS companies, ranging from $82 \%$ in the Americas to $38 \%$ in Africa. Only $16 \%$ had published conflict of interest policies, statements or guidelines [151]. This study did not assess sponsorship of other professions, and therefore represents a fraction of total industry engagement. A prominent example, is Big Formula's long historical relationship with the American Academy of Pediatrics (AAP). As of 2017, excluding payments for advertising and conference exhibits, the AAP was receiving US\$3.3 million from four companies every year, accounting for $\sim 3 \%$ of its annual budget [121]. Big Formula leveraged this relationship through cobranding when, in 2013, US hospitals were reportedly distributing discharge packs of formula samples bearing the AAP logo, and copies of the AAP book on breastfeeding bearing a company brand. This arrangement has since been discontinued [121, 152].

Strategies have also been used to co-opt health professionals in the marketing of specialised formulas [153]. Such formulas are for conditions affecting a small proportion of the infant population, including premature birth, diarrhoea, allergy treatment and prevention [42, 154]. Prescribing behaviours are shaped by research activities, clinical guideline development, medical education and public awareness - all activities Big Formula influences. Industry-driven over-diagnosis of cows-milk protein allergy (CMPA) in particular, has contributed to rapid sales growth in specialised formula sales. In the UK, for example, between 2006 and 2016 specialised formula prescriptions for infants with CMPA increased $500 \%$ from 105,029 to 600,000 , a rate greatly exceeding any credible change in actual prevalence. This reflected a $\sim 700 \%$ increase in expenditure by the National Health Service on these products from $£ 8.1$ million to $>£ 60$ million [153]. The baby food industry, or its marketing consultants, funded the development of at least three clinical guidelines on CMPA, with $81 \%$ of all guideline authors reporting a conflict of interest. Furthermore, recommendations made to manage the symptoms as CMA, were found to lack supporting conclusive evidence [153].

Big Formula also works with health professionals to redefine the adaptive food selection behaviours of young children as deviant and abnormal, as conditions that can be eliminated through the use of their products. For example, by collaborating with psychologists, dietitians, and physicians, Abbott, created a new definition for a condition termed 'feeding difficulties' [155]. To establish a standard for helping paediatricians accurately identify and manage children with this newly created condition, Abbott funded researchers developed the IMFeD (Identification and Management of Feeding Difficulties for Children) tool in 2011 [156]. Marketing was then employed to fuel awareness of 'picky eating' amongst consumers, and to associate this syndrome with poor cognitive and social outcomes for children, thereby appealing to parental anxieties. Advertisements and advice for health professionals focused on prescribing enriched formula milk to children to prevent this 'state' [157].

\section{Capturing the science and knowledge environments}

Another key representation of Big Formula's power over first-foods systems, is scientific capture [158, 159]. To legitimise their products and to support their engagement with health professionals, policy-makers and consumers, Big Formula has acquired vast scientific research capabilities, coordinated through corporate nutrition research divisions, philanthropic foundations and external partners (Table 6). Nestlé, for example, has 'the world's largest private nutrition research capability' with 'nutritional expertise in every market' [160]. The Nestlé Nutrition Institute, is not only a 'continuing education platform' for health professionals, but also the 'world's largest private food and nutrition research organization', employing $\sim 5000$ staff across 30 facilities worldwide, and generating $\sim 200$ peer-reviewed research articles every year [161].

The research generated (and funded) by these platforms promotes a biomedical and nutrient-centric interpretation of infant and young child nutrition, typically focusing on the 'fortification' of baby foods (e.g. micronutrient fortified infant cereals), the 'reformulation' of products to enhance their nutrient profile (e.g. reduced lactose formulas), or the development of novel product ingredients that 'functionalise' their products (e.g. human-milk oligosaccharides) $[49,162]$. Such research enables Big Formula to exercise discursive power, and institutionalise certain beliefs and practices in several ways. First, to drive sales by actively portraying their products 'as close as possible to breastmilk', and to amplify this message through actual or implied claims about the health and developmental benefits of their products, to both health professionals and consumers (see marketing strategies) [163-165]. Second, it shapes wider public perceptions about infant and young child nutrition, by rendering milk formulas as safe, nutritionally adequate and scientific, thereby detracting from the wider health implications of their products [49, 163, 166]. Third, by framing these efforts as part of corporate social responsibility initiatives, this science further legitimises their image as responsible corporate actors and desirable policy partners [49].

Scientific capture also extends into population-level nutrition surveillance research. This not only serves to inform product development across Big Formula's diverse markets, but also to engage with policy-makers, and through partnerships, with various professional 
Table 6 Big Formula's corporate nutrition research divisions and philanthropic units, their research capabilities and listed activities

\begin{tabular}{|c|c|c|c|c|c|}
\hline Corporation & Nestlé & Danone & RBMJ & Abbott & RFC \\
\hline \multicolumn{6}{|c|}{ Corporate nutrition research divisions } \\
\hline $\begin{array}{l}\text { Nutrition } \\
\text { research } \\
\text { division }\end{array}$ & $\begin{array}{l}\text { Nestlé Nutrition Institute } \\
\text { (1981) } \\
\text { (Not-for-profit } \\
\text { association) }\end{array}$ & $\begin{array}{l}\text { Danone Institute } \\
\text { International (1991) } \\
\text { (Non-profit } \\
\text { organizations) }\end{array}$ & $\begin{array}{l}\text { Mead Johnson Pediatric } \\
\text { Nutrition Institute }\end{array}$ & $\begin{array}{l}\text { Abbott Nutrition Health } \\
\text { Institute (2007) }\end{array}$ & $\begin{array}{l}\text { FrieslandCampina } \\
\text { Institute (2001) }\end{array}$ \\
\hline $\begin{array}{l}\text { Statement of } \\
\text { purpose, aim or } \\
\text { mission }\end{array}$ & $\begin{array}{l}\text { 'To bring nutrition } \\
\text { science to life through } \\
\text { the people who live it; } \\
\text { connecting a world of } \\
\text { healthcare providers, } \\
\text { generating discussion } \\
\text { and encouraging } \\
\text { relevant conversations.' }\end{array}$ & $\begin{array}{l}\text {... to promote human } \\
\text { health by developing } \\
\text { and disseminating } \\
\text { knowledge about the } \\
\text { links between food and } \\
\text { human health, and to } \\
\text { highlight the } \\
\text { importance of nutrition } \\
\text { in human health.' }\end{array}$ & $\begin{array}{l}\text { '... deliver products } \\
\text { with an } \\
\text { uncompromising } \\
\text { commitment to quality } \\
\text { and safety ... connects } \\
\text { innovative scientific } \\
\text { technology and } \\
\text { research with cutting- } \\
\text { edge manufacturing } \\
\text { and quality processes.' }\end{array}$ & $\begin{array}{l}\text { '... to connect and } \\
\text { empower people } \\
\text { through science-based } \\
\text { nutrition resources to } \\
\text { optimize health } \\
\text { worldwide.' }\end{array}$ & $\begin{array}{l}\text { '... shares knowledge } \\
\text { and expertise on the } \\
\text { nutritional properties of } \\
\text { milk and dairy products } \\
\text { with nutrition and } \\
\text { health professionals, to } \\
\text { improve the health and } \\
\text { well-being of people } \\
\text { worldwide.' }\end{array}$ \\
\hline $\begin{array}{l}\text { Statement of } \\
\text { capability }\end{array}$ & $\begin{array}{l}\text { The world's largest } \\
\text { private food and } \\
\text { nutrition research } \\
\text { organisation, involving } \\
\text { around } 5000 \text { people } \\
\text { located in around } 30 \\
\text { R\&D facilities worldwide.' }\end{array}$ & $\begin{array}{l}\text { '... network of } 14 \\
\text { Danone Institutes ( } 13 \\
\text { local Institutes and } 1 \\
\text { International) ... present } \\
\text { in } 15 \text { countries and } \\
\text { gather around } 200 \\
\text { experts around the } \\
\text { World (nutritionists, } \\
\text { pediatricians, } \\
\text { gastroenterologists, } \\
\text { scientists, sociologists } \\
\ldots)^{\prime}\end{array}$ & $\begin{array}{l}\text { '... growing global } \\
\text { network of ... scientists, } \\
\text { research laboratories } \\
\text { and facilities ... Since } \\
2010 \text {... four new MJPNI } \\
\text { research and } \\
\text { development } \\
\text { technology centers ... } \\
\text { in the U.S., Mexico, } \\
\text { China and Singapore.' }\end{array}$ & $\begin{array}{l}\text { 'Today we support and } \\
\text { empower half a million } \\
\text { healthcare professionals } \\
\text { and the millions of } \\
\text { patients they serve.' }\end{array}$ & $\begin{array}{l}\text { '... approximately } 600 \\
\text {.. experts across the } \\
\text { world'; Institutes in } \\
\text { North America, Europe } \\
\text { (Netherlands), Asia } \\
\text { (Singapore), and Africa; } \\
\text { partnerships with } \\
\text { dietetic associations, } \\
\text { universities and dairy } \\
\text { industry communication } \\
\text { platforms }\end{array}$ \\
\hline $\begin{array}{l}\text { Relevant } \\
\text { activities listed } \\
\text { on website }\end{array}$ & $\begin{array}{l}\text { Digital platform for } \\
\text { sharing free resources } \\
\text { and content; accredited } \\
\text { e-learning \& continuing } \\
\text { medical education pro- } \\
\text { grams; workshops and } \\
\text { symposia presentations } \\
\text { at congresses; research } \\
\text { fellowships in paediatric } \\
\text { nutrition and } \\
\text { gastroenterology. }\end{array}$ & $\begin{array}{l}\text { Research support } \\
\text { through 'credits, grants, } \\
\text { awards, fellowships and } \\
\text { scholarships'; including } \\
\text { 'more than } 20 \text { different } \\
\text { research support } \\
\text { programs in } 12 \\
\text { countries'; nutrition } \\
\text { research prizes; } \\
\text { conferences and } \\
\text { symposia; publications; } \\
\text { nutrition education } \\
\text { tools for children. }\end{array}$ & $\begin{array}{l}\text { Research and } \\
\text { development; medical } \\
\text { education grants } \\
\text { provides grant funding } \\
\text { for continuing medical } \\
\text { education; provides } \\
\text { child nutrition advice for } \\
\text { parents. }\end{array}$ & $\begin{array}{l}\text { Continuing medical } \\
\text { education via online } \\
\text { forum, blog site, } \\
\text { certificates of training; } \\
\text { materials on therapeutic } \\
\text { pediatric nutrition; } \\
\text { podcasts, webinars and } \\
\text { videos on various } \\
\text { pediatric nutrition and } \\
\text { feeding topics; } \\
\text { infographics, scientific } \\
\text { articles and briefs. }\end{array}$ & $\begin{array}{l}\text { Stimulating scientific } \\
\text { debate and sharing } \\
\text { knowledge; engaging } \\
\text { governments, NGOs, } \\
\text { institutes, scientists and } \\
\text { nutrition \& health } \\
\text { professionals; provides } \\
\text { accredited continuing } \\
\text { education programs, } \\
\text { scientific information, } \\
\text { and practical tools. }\end{array}$ \\
\hline \multicolumn{6}{|c|}{ Corporate philanthropic units } \\
\hline $\begin{array}{l}\text { Philanthropic } \\
\text { unit }\end{array}$ & $\begin{array}{l}\text { Nestlé Foundation for } \\
\text { the Study of Problems of } \\
\text { Nutrition (1966) }\end{array}$ & Social Innovation Funds & $\begin{array}{l}\text { RB Fight for Access } \\
\text { Fund } \\
(2020)\end{array}$ & $\begin{array}{l}\text { The Abbott Fund } \\
\text { (1951) }\end{array}$ & - \\
\hline Status & Philanthropic foundation & Various & $\begin{array}{l}\text { Philanthropic } \\
\text { foundation }\end{array}$ & Philanthropic foundation & - \\
\hline Focus & $\begin{array}{l}\text { Initiates and supports } \\
\text { research in human } \\
\text { nutrition with public- } \\
\text { health relevance in } \\
\text { LMICs on maternal and } \\
\text { child nutrition, including } \\
\text { breastfeeding and com- } \\
\text { plementary feeding; nu- } \\
\text { trient deficiencies and } \\
\text { imbalances; interactions } \\
\text { between infection and } \\
\text { nutrition; and nutrition } \\
\text { education and health } \\
\text { promotion. }\end{array}$ & $\begin{array}{l}\text { We want to support } \\
\text { people in adopting } \\
\text { healthier and more } \\
\text { sustainable eating and } \\
\text { drinking practices, and } \\
\text { we want to do this in a } \\
\text { way that is aligned with } \\
\text { our long term } \\
\text { commitment to } \\
\text { economic success and } \\
\text { social progress.' }\end{array}$ & $\begin{array}{l}\text { 'To improve access to } \\
\text { health, hygiene and } \\
\text { nutrition for all. The } \\
\text { Fund is, and will, be a } \\
\text { demonstration of our } \\
\text { Purpose and Fight in } \\
\text { action- to protect, heal } \\
\text { and nurture in the } \\
\text { relentless pursuit of a } \\
\text { cleaner, healthier world.' }\end{array}$ & $\begin{array}{l}\text { We invest in innovative } \\
\text { ideas that expand } \\
\text { access to health care, } \\
\text { strengthen communities } \\
\text { where we live and } \\
\text { operate, and promote } \\
\text { science and medical } \\
\text { education. In } \\
\text { partnership with others, } \\
\text { we strive to make a } \\
\text { lasting impact on } \\
\text { people's lives and } \\
\text { encourage others to } \\
\text { take positive action.' }\end{array}$ & - \\
\hline
\end{tabular}


associations, universities and research institutes. For example, RFC has partnered in the South East Asia Nutrition Survey, involving 16,744 children across Malaysia, Indonesia, Thailand and Vietnam, resulting in a better understanding of the diet, health, dietary needs and general dietary patterns of children in Southeast Asia'. Furthermore, the '.. findings of the survey have helped local governments and policy makers to develop and implement a scientifically grounded nutrition policy for children in Southeast Asia' [167]. The purpose of Nestlé's Feeding Infants and Toddlers Study (FITS) and Kids Nutrition and Health Study (KIDS) is 'to explore eating patterns, nutrient intakes and food sources of nutrients among infants and children in different countries around the world'. These have involved 'large-scale crosssectional surveys' in Brazil, China, Nigeria, UAE and the US, and studies using national survey data in Australia, China, Mexico, the Philippines and Russia. Since 2002, these studies have collectively generated $\sim 90$ articles with $\sim 100$ collaborators $[168,169]$.

Big Formula also coordinates with other corporate actors, to generate and promote favourable research and knowledge environments. For example, Abbott, RBMJ and Danone, along with various transnational food corporations, are members of the International Life Sciences Institute (ILSI), a corporate-funded organization founded in 1978 by a Coca-Cola Scientific and Regulatory Affairs executive, with the aim of promoting 'global partnerships for a healthier world' [170]. Nestlé withdrew its membership in 2020 (this followed the withdrawal of Mars in 2018, citing concerns with ILSI's 'advocacy-led studies') [170]. Despite its claim of being a neutral scientific organization, ILSI members promote industry positions informing health policy responses across many countries and nutrition issues [171-173]. Through its Washington D.C. headquarters, and eighteen branches, its member activities are coordinated across all regions under a 'One-ILSI' strategy [170]. As an example, in 2008-2009 members established the South East Asia Region's Technical Committee and Expert Panel on Maternal, Infant and Young Child Nutrition. During this period in collaboration with seven regional health and research agencies, a total of six Expert Consultations, 11 Seminars and Workshops [were] held in the region with 13 scientific papers published in peer-reviewed journals'. Demonstrating its reach and influence, 'About 1,000 nutrition, public health and pediatric professionals from government agencies, health and research institutions, NGOs and the private sector attended the meetings' [174].

\section{Marketing strategies}

As they accumulate greater resources, Big Formula can employ world-leading advertising, branding and public relations agencies, to implement more intensive and sophisticated forms of marketing [4]. The term 'marketing' includes a set of corporate strategies - the so-called 'marketing mix' - including product design, pricing, advertising and promotion, retail placement and public relations strategies, among others. Such marketing effectively undermines breastfeeding; exposure is associated with reduced initiation, exclusivity and duration in all country contexts [13-15]. Within countries, marketing exposure appears to 'cascade', concentrating initially in first-tier cities with higher income consumers, before becoming more prominent in peri-urban areas, lowertier cities and towns, as has occurred in China [175].

Big Formula are among the world's most recognised and valuable brands, and largest advertising spenders. Nestlé, for example, is among the world's most recognised household names, with its brand valued at \$US12.6 billion in 2019, ranked 50th among global brands. The company spent an estimated US\$9.9 billion on 'consumer facing' advertising in 2016, the third highest spender worldwide [176]. Although we could not source data on Big Formula's marketing expenditures specifically, we used a conservative estimate of 3-10\% of sales [42], to estimate a global spend of between US\$1.68-5.56 billion in 2019. These figures far outweigh any expenditure on breastfeeding promotion by governments, international organizations and global health donors [146]. Some national marketing data are available, and indicate a significant increase in expenditure on milk formulas for older infants and young children, relative to infant formula. For example, in 2015, three companies Nestlé, Abbott and Mead Johnson spent US\$9.75 million on advertising infant formula in the US market, and US\$16.83 million advertising toddler milk [41].

Big Formula contract agencies to develop and execute their strategies. The globalization and consolidation of the advertising sector since the 1980s has been well described. A small number of 'global communications groups' based in the US, Europe and Japan, control most of the world market through networks of subsidiary agencies. These have typically followed their corporate clients into new markets, hence globalizing alongside them, and providing coordinated services across diverse markets $[28,86]$. This sector features significantly in Big Formula's global influence network (Fig. 3). The entry of a corporation into a new market can change the intensity and forms of marketing by the industry as a whole. For example, prior to the mid-1980s, the three largest US manufacturers practiced a voluntary ban on advertising in agreement with the American Academy of Pediatrics (AAP), and as pharmaceutical companies, they could rely upon their extensive sales networks to health care providers. With no such network in place, Nestlé decided to ignore this agreement when it entered the market in 1985, and began direct-to- 
consumer advertising in 1988 [71]. In 1993, it filed a lawsuit against the US companies and the AAP, claiming the advertising ban was a barrier to trade in violation of US competition law [27].

The first key pillar of Big Formula's marketing strategy is health professional co-optation, which we have already described (see co-opting health professionals). Direct-toconsumer advertising is the second pillar. Traditional advertising channels include parenting magazines, television and in-store retail displays $[40,146]$. As digital technologies expand worldwide, parents and especially mothers, are increasingly engaged through social media platforms, parenting forums, mobile apps, e-commerce sites, reward programmes and sponsored parenting blogs [146, 164, 177, 178]. Celebrities and other influencers are employed to promote products on social media, and to host events on- and offline $[178,179]$. Health professionals and other experts host question and answer sessions and webinars on infant feeding and other lifestyle topics on social media $[179,180]$. Advertisements often contain links to clubs, carelines and promotion lines, where women are encouraged to engage with industry representatives and health professionals in a one- to-one conversation [181].

'Big Data' analytics platforms enable sophisticated forms of market segmentation and targeting, as personal data can be collected and then used to generate tailored, and even personalised, advertisements to parents differentiated by, for example, income, parenting stage and lifestyle [19, 41, 42, 182]. Messages often portray milk formula as a symbol of modernity, as equivalent with or superior to breast milk, and formula-feeding as extensively practised, and as a desirable lifestyle choice [41, 146, 183]. Appeals are made to the emotional and psychological aspects of parenting (e.g. 'when mothers milk fails' and 'freedom from judgement'), tensions between formula-feeding and breastfeeding parents (e.g. Abbott's The Sisterhood of Motherhood campaign), and parental aspirations (e.g. child learning ability, paternal bonding, and minimising parent-child conflict) [41, 183].

The third key pillar of Big Formula's market strategy, is product innovation. In a process of market segmentation, the creation of entirely new product categories is used to not only to generate new sales growth, but also to circumvent marketing regulation. By the late 1970s, 200 infant formula products and 50 brands were reportedly available across 100 countries [42]. However, prior to The Code infant formula was the main product category, promoted 'from birth' without upper-age limit. From 1984 onwards, just as governments were beginning to implement The Code, the marketing of follow-up formulas and toddler-milks markedly intensified, and soon became widely available. This was described by one industry report as the renaming of products 'primarily to avoid regulation and restrictions on advertising' applying to the first 6 months only [21]. By using nearly identical branding and labelling across their entire product range, Big Formula have 'cross-promoted' their products, including infant formula in countries where legislation prohibits this $[42,165,166,184]$. This strategy of cross-promotion also extends from 'womb-to-tomb', through branded milk formula products for all life-stages, including infants and young children, but also for pregnant and lactating mothers, older children and adolescents, and the elderly (i.e. grandparents) who are also often involved in making feeding decisions [42].

Finally, Big Formula's aforementioned scientific capabilities are also used to support 'nutritional positioning', a marketing technique involving the development of products with novel ingredients and implied or direct health claims, often on premium or specialised products that sell for markedly higher prices [42, 163-165]. Ingredients once found only in specialised formulas have been increasingly added to nearly all products. Many claims have no publically available evidence, or only poor-quality evidence, to support them $[185,186]$. The evidence that does exist, often cites studies directly sponsored by Big Formula [187]. Claims made on product labels include inter alia those relating to brain, eye and immune system development, reduced allergies, and to specific outcomes linked with normal infant behaviours, including sleeplessness, fussiness and regurgitation [188, 189]. These claims are supported by the addition of functional ingredients claimed to mimic breastmilk (e.g. human-milk oligosaccharides, essential fatty acids, and probiotics), or reformulated ingredients (e.g. reduced lactose) $[186,188]$.

When combined, these techniques powerfully influence social norms and beliefs about what feeding practices are considered normal, acceptable and socially desirable $[42,146]$. For example, one recent US survey found $52 \%$ of caregivers agreed with the statement that infant formula can be better for babies' digestion and brain development than breastmilk; $62 \%$ that it can provide nutrition not present in breastmilk [161].

\section{Discussion}

Here we consider how this study advances our understanding of corporate power and the commercial determinants of maternal, newborn and child health. Our results show that milk formula is a phenomenal commercial success - a global market worth $\sim$ US1.5 billion in 1978 , is today worth US $\$ 55.6$ billion, representing a 36 -fold increase over a 40 -year period. How then, inspite of The Code, and the ever-growing evidence on the harms of formula-feeding, has the industry managed to sustain this remarkable growth? In our view, this historical expansion reflects the core underlying driver of capitalism itself - the pursuit of profit and capital accumulation - and through this pursuit, the subjugation of the mother-child breastfeeding dyad to corporate 
power, and the transformation of first-foods systems to promote and sustain high levels of milk formula consumption.

\section{Commodifying the mother-child feeding dyad}

The global rise of milk formula, by necessity, requires the transformation of infant and young child feeding into an object of trade. This has involved the replacement of breastfeeding, as the biological norm and firstfood supply chain, with formula-feeding and commercial supply chains, across an ever-widening population of children. Our results show this process has occurred along two main historical axes.

First, through the expanding geographical reach of milk formula marketing. Across countries, this has involved a handful of corporations originating mainly in the advanced capitalist economies of Europe and the United States, expanding initially in the Global North alongside historic declines in breastfeeding, and then as those markets have matured and stagnated, expanding intensively into countries throughout the Global South, with much higher, although in some cases now greatly diminished, breastfeeding rates. Within countries, markets appear to expand first among urban elites in major urban centres, before spreading more widely into lowertier cities and towns, and among poorer population groups. The growth of modern retail outlets, the increasing hospitalisation and medicalization of birth, and the emergence of large-scale grey market trade, have created key distribution channels for making milk formula widely available.

Second, through widening the boundaries of motherchild populations subject to commodification. Product ranges have expanded from largely a single infant formula category prior to the 1980s, to include follow-up formulas, toddler milks and an array of specialised formulas, along with milks for pregnant and lactating mothers and so on. Industry-driven over-diagnosis, the invention of new feeding 'conditions', and the expanded consumption of specialised milks that results from this, is consistent with a strategy of 'disease-mongering', intended to widen the 'boundaries of illness and grow the markets for those who sell and deliver treatments' [190]. This combined process of market segmentation and mongering has greatly expanded the age range of children consuming formula, and indeed the consumption of branded milk drinks across the entire life-course [37].

\section{The power of marketing}

As markets have expanded in both geographical reach and population scope, Big Formula have used sophisticated marketing techniques to influence choice, drive consumption, and normalise formula-feeding across diverse country contexts. Arguably, as this normalisation occurs, corporations become key (if not the main) custodians of knowledge and education about infant and young child feeding. This power is enabled through massive expenditures on branding, advertising and sales promotion, bolstered by the creative expertise of global advertising agencies. Corporate science conducted by the corporations themselves, and through engagement with external scientists and organizations, is used to support and amplify this marketing. Broadly consistent with earlier studies [37, 41, 146, 191], we identify three key pillars of Big Formula's marketing strategies.

First, is health professional co-option to 'secure the recommendation', distribute formula through health systems, and legitimise milk formula products as safe, scientific and medically-endorsed. Notably, we identify the significant structural power Big Formula holds over the training of health professionals in paediatric nutrition, and infant and young child feeding more broadly, through wide-reaching sponsorship of professional associations, and through the direct provision of professional education, including through large-scale e-learning platforms. The power of this 'corporate education' is amplified, when breastfeeding is often excluded from the curricula of healthcare professional training providers a serious problem recognised worldwide [192-194].

Second, direct-to-consumer advertising occurs through mass- and digital media. Messaging promotes formula as scientific, medically-endorsed, and as equivalent with, or as superior to breast milk, along with appeals to parental anxieties, aspirations and lifestyles [41, 146, 183]. Global growth in digital technologies, including social media and smart phones, has enabled sophisticated new data collection and analytical techniques, to personalise and deploy targeted advertisements. The power of digital marketing should not be underestimated, and likely represents a key driver of the recent surge in global milk formula sales, as well as a key challenge for national regulators [181]. The Committee on the Rights of the Child recognises the potential for digital advertising and marketing to violate or abuse child's rights, and calls on governments to prohibit by law, the profiling or targeting of children [195].

Third, are product innovations. The segmentation and extension of milk formula product ranges not only widens the boundaries of markets and cultivates new demand, as described earlier; it also enables the crosspromotion of products across the entire branded range, and the circumvention of marketing regulations applying to infant formula only [42, 46, 184]. Nutritional positioning, involving the development of novel products with reformulated and functional ingredients, and the use of direct or implied health claims, reinforces an image of milk formula as an optimal form of early-life nutrition [42, 163-165]. These are marketing techniques requiring much greater scrutiny by regulators. 


\section{The power to market}

However, the capacity to deploy the marketing techniques described above is only possible because of the large investments the baby food industry makes in fostering policy, regulatory and knowledge environments conducive to such marketing in the first place. We find extensive evidence of the industry's political practices, coordinated on a global scale, to achieve this. When considered together, these demonstrate two faces of corporate power - a more hidden, covert one, involving strategies to constrain critical discourse, co-opt opponents, and curtail regulatory threats; and a more visible public-facing one, to foster an image of corporate social responsibility, and maintain their 'social license' to operate $[28,31,44]$. These practices are broadly consistent with those identified in studies on the tobacco, alcohol and ultra-processed food industries (e.g. [196-198]), and how neo-liberal economic globalization has markedly strengthened the power of these industries, to grow and sustain their markets, e.g. [58, 85, 196-199]).

First, the baby food industry employs a large global influence network, comprising many trade associations, addressing diverse corporate issues and regulatory threats. Lobbying practices by this network are often less visible or invisible to outside scrutiny, and appear to be coordinated on a global-scale. Such practices are strongly incoherent with Big Formula's corporate social responsibility initiatives. The corporations state they abide by their own policies, and by the laws in the countries in which they operate; but then belong to trade associations that lobby against the adoption of those very same laws. Hence they foster an image of responsible conduct, but allow third-parties to undermine breastfeeding on their behalf, without tarnishing their reputation. This might be referred to as a strategy of 'political distancing'.

Infant and nutrition trade associations, which are largely funded by Big Formula, appear to be 'core' to this network. Others, including branding and advertising associations, also potentially represent key impediments to worldwide implementation of The Code, although this requires further investigation. In the US we found that lobbying expenditures declared by Big Formula are extensive, and highly targeted at various government agencies, yet have declined. This may reflect actual declines, or a reduction in corporate disclosure, or reductions in the cost of lobbying. It is also possible that lobbying activities have become increasingly outsourced.

Second, Big Formula's corporate policies on responsible marketing are consistent with a strategy of 'policy substitution', one that aims to pre-empt, delay and/or replace regulation by the state. Although The Code stipulates manufacturers and distributors should monitor their marketing practices according to the principles and aim of [The Code], and ... ensure that their conduct at every level conforms to them' [32], their selfregulatory initiatives establish a global response far short of compliance with The Code. At the same time, the legitimisation of this self-regulation through third party corporate accountability initiatives, helps to portray Big Formula as responsible corporate citizens, while simultaneously deflecting blame, and co-opting moderate opponents $[48,200]$. This image of responsible conduct, is further bolstered by strategic corporate philanthropy. This not only includes social and environmental initiatives, but also what we call 'crisis marketing', including large-scale product donations and others marketing techniques to exploit emergencies, or crises, like Covid19.

Third, the governments of large dairy-producing and exporting nations have consistently acted on the industry's behalf to influence standard-setting processes in international policy fora, and taken bilateral actions to weaken implementation of The Code by other governments through 'economic diplomacy'. At the international level, three multi-lateral institutions have been the focus of this influence - the WHO, CAC, and the WTO, that together establish and (in the case of WTO) enforce standards, on the marketing, safety, labelling, composition and trade of BMS [Russ K, Baker P, Byrd M, Kang M, Siregar RN, Zahid H, McCoy D: Understanding the global trade and public health regime complex: a case study on breastfeeding and commercial breastmilk substitutes. Forthcoming]. In CAC standardsetting processes, the distinction between 'member state delegate' and 'industry observer' is somewhat blurred, and very often industry representatives are the member state. Such standard-setting processes therefore appear to be strongly 'captured', suggesting the need for much greater scrutiny of how industry participates at Codex, and how to bolster representation by public-interest civil society groups.

Many governments have been challenged in the WTO when attempting to implement The Code into national law, and in several cases this has resulted in weakening of the scope and strength of regulation. It is also likely this has a much wider 'chilling' effect on other governments, who after having observed these challenges, re-consider their own commitment to regulate BMS [58]. The US Government in particular, has been a remarkable force in weakening the legal status and provisions of The Code at the WHA, and its implementation by other governments into national law. This appears to be linked with a small number of US corporations and trade associations, who have consistently lobbied US Government agencies on BMS-related trade issues. This represents a major area of policy incoherence for the US Government, given it is the 
largest contributor of overseas development assistance for breastfeeding [201].

Finally, the baby food industry is currently undergoing terminal consolidation with markets now moderately to strongly oligopolistic. With consolidation, Big Formula have accumulated vast material resources, and become structurally important within various national economies as suppliers of jobs, investments and export earnings [2, 202]. As a result, governments have directly supported the industry's growth through lax domestic regulations and other policy measures. For example, the US, Canada, New Zealand and Australia, all major milk formula and dairy producing nations, have yet to adopt any provisions of The Code into national law.

The US Government effectively subsidises the industry, by purchasing half of all formula sold through its WIC Program [124, 125]. In China, the Government provides direct support through a whole-of-government policy, including tax cuts, approvals for industry consolidation, and finance to support foreign acquisitions [203]. Food regulatory environments in many countries are permissive of health and nutrition claims on milk formula products, with low-evidential requirements, thereby enabling the marketing technique of 'nutritional positioning'. This calls into question whether existing regulatory systems are fit-for-purpose in meeting public health objectives $[185,204]$.

\section{Limitations and strengths}

This study has several limitations and gaps, which require investigation. First, there is a strong US-bias in our data. This is because US corporate lobbying disclosure and transparency laws have enabled us to access relevant data, whereas we were unable to source useful comparable data from the EU or elsewhere. Second, we have not examined the financiers behind the baby food industry. Others have reported on how the financialization of the global economy, involving the emergence of a liberal financial regime, has helped facilitate the global value chain integration of transnational corporations, and provided access to finance and risk management techniques for accelerated global expansion [19, 205]. Furthermore, we have given only cursory consideration to the evolving yet important role of the global trade and investment regime, in facilitating milk formula market expansion.

Third, we have not engaged with feminist economic perspectives to understand the core economic drivers of first-foods systems, including the underlying (dis) incentives that compel governments and other actors to support the growth of milk formula markets over breastfeeding [5]. For example, commercial milk formulas are represented by industry groups and governments as high-value export commodities that support 'jobs and growth', and get 'counted' in national accounting systems and gross domestic product (GDP), whereas the immense societal value of breastfeeding and other forms of informal care work provided by mothers, does not. Fourth, we have not considered the role of manufacturers and distributors of bottles, teats and other feeding apparatuses in shaping first-foods systems, although these products are also covered by The Code.

Fifth, we have not considered the overall distributive effects of the industry. Yet, not breastfeeding generates global economic losses of US\$341.3 billion annually, resulting from higher health care costs, premature mortality and lost productivity [9]. The production of ingredients and the manufacturing and consumption of milk formula generates significant environmental harms, including water pollution, greenhouse gas emissions and packaging waste [206]. Hence the power of Big Formula to expand markets, and accumulate profits, extends at least partly from its power to externalise the social, economic and environmental costs of production. These wider distributive effects of the industry, and its contribution to sustainable economic development, requires much greater scrutiny.

Finally, we have not directly examined how corporate power influences feeding practices by the mother-child feeding dyad itself. Research on ultra-processed foods suggests that market expansion is partly enabled by a skills transition, as consumers appropriate new 'technoskills' required to source, prepare and consume such foods [19]. The same is likely true for milk formulas the skill of breastfeeding, which has traditionally been transferred inter-generationally through women-towomen and kin-based relationships [6], is displaced by new skills required for artificial feeding, informed by 'commercial education' and marketing [28].

The main strength of this synthesis is that we describe how corporate power works to shape first-foods systems in their entirety, rather than just focusing on certain features or sub-systems. In doing so, we have provided a macroscopic understanding of how corporate power works, across an entire system, historically and in global context. We were able to do this by using a multidisciplinary approach and theoretical framework to guide the study, thereby increasingly the likelihood we captured the main market and political practices of the industry. This was also enabled by drawing from diverse data sources, including extant literature, but also new empirical data where the literature was sparse or missing altogether, as well as the perspectives of our large multidisciplinary research team.

\section{Conclusion}

Milk formula, first invented in Europe in the 1860s as a specialised product for the small proportion of the infant population unable to breastfeed, has become a massproduced consumer good, available nearly everywhere. 
Our findings show how Big Formula, and the wider industry, have used diverse market and political practices to powerfully shape first-foods systems in ways that drive the expansion of milk formula markets on a global scale. This has resulted in an unprecedented increase in the number of children consuming milk formula worldwide, and represents a significant impediment to global progress on breastfeeding. The historical expansion of the industry has occurred across two main axes - first, through the expanding geographical reach of milk formula markets across and within countries; and second, the broadening of milk formula product ranges, and hence the scope of mother-child populations subject to commodification.

The industry has harnessed the power of marketing to grow and sustain high levels of milk formula consumption, including most recently through the use of sophisticated digital marketing techniques. Despite The Code, and other public health actions to curtail the industry's marketing practices, milk formula markets have massively expanded. This power of marketing is only made possible, because of the large investments made by the industry in fostering favourable policy, regulatory and knowledge environments that enable and sustain such marketing in the first place. Responding to this challenge, and accelerating global progress on breastfeeding, will require the strengthening of worldwide actions to constrain the power of marketing, including through the use of law and government intervention. However, it will also require actions to constrain the baby food industry's power to market, by targeting the political practices of the corporations, and their global network of trade associations and other corporate-funded influence organizations. This presents a formidable challenge, and suggests that new modalities of public health action are urgently needed.

\section{Supplementary Information}

The online version contains supplementary material available at https://doi. org/10.1186/s12992-021-00708-1.

\section{Additional file 1: Figure S1. Global dry milk powder production and trade dynamics in 2005 (top) and 2014 (bottom) - circles represent country production values (tonnes), and lines the value and direction of trade (US\$). Notes: To simplify the figure, only countries with trade flow (export) values > US\$10 million were represented; dry milk powder production values (tonnes) were sourced from FAOSTAT. Trade data were soured from UN Comtrade. Table S1. List of organizations in the baby food industries' global influence network. Notes: * formerly the Grocery Manufacturers Association.}

\section{Acknowledgments}

The authors kindly thank Ellen Piwoz for her useful comments and suggestions, which helped to greatly enhance the manuscript.

\section{Authors' contributions}

PB and DM proposed the study and co-designed the theoretical framework, with guidance and conceptual insights from ML, RM, BW, MM, JS and DC. PB designed the study and led overall data collection, analysis and drafting of the manuscript. KR and MK led collection and analysis of data on lobbying and trade, and contributed significantly to sections describing the political practices of the industry. GS provided content in several sections describing health professional co-optation and marketing. KS assisted with the search for documentary evidence. MB led data collection of the CAC data quantifying stakeholder participation. TM and PN provided guidance on quantitative data analysis in some sections, and generated severalof the final figures. GS provided content in several sections describing health professional cooptation and marketing. All authors provided written inputs into the manuscript, provided comments on draft revisions, and approved the final version.

\section{Funding}

This work was supported by funding from the Department of Maternal, Newborn, Child and Adolescent Health, World Health Organization. The findings reported in this manuscript reflect the viewpoints and findings of the authors only, and do not necessarily represent those of the study funder.

\section{Availability of data and materials}

All data generated or analysed during this study are included or cited in this published article and its supplementary information files. The information contained in this manuscript has been obtained from sources believed to be reliable. However, any potential interpretation of the findings as making an allegation against a specific named company or companies would be incorrect and misleading.

\section{Declarations}

\section{Ethics approval and consent to participate}

This study was approved by the Deakin University Human Research Ethics Committee. There were no participants in this study, hence consent requirements were not applicable.

\section{Consent for publication}

Not applicable.

\section{Competing interests}

$\mathrm{ML}$ is a member of the Food Standards Australia New Zealand Board and several committees, the views expressed in this manuscript do not necessarily represent the views, decisions or policies of the institutions with which he is associated.

\section{Author details}

${ }^{1}$ Institute for Physical Activity and Nutrition, Deakin University, Geelong Australia. ${ }^{2}$ University of California, Davis, CA, USA. ${ }^{3}$ International Centre for Equity in Health, Federal University of Pelotas, Pelotas, Brazil. ${ }^{4}$ Research School of Population Health, Australian National University, Canberra, Australia. ${ }^{5}$ Centre for Primary Care and Public Health, Queen Mary University, London, UK. ${ }^{6}$ Trinity Business School, Trinity College Dublin, Dublin, Ireland. ${ }^{7}$ School of Health and Social Development, Deakin University, Geelong, Australia. ${ }^{8}$ Melbourne School of Population and Global Health, University of Melbourne, Melbourne, Australia. ${ }^{9}$ Independent Consultant on Public Health Law, New York, USA. ${ }^{10}$ School of Exercise and Nutrition Sciences, Deakin University, Geelong, Australia.

Received: 21 January 2021 Accepted: 29 April 2021

Published online: 21 May 2021

\section{References}

1. Hastings $\mathrm{G}$. Why corporate power is a public health priority. Br Med J. 2012; 345 https://doi.org/10.1136/bmj.e5124.

2. Moodie R, Stuckler D, Monteiro C, Sheron N, Neal B, Thamarangsi T, et al. Profits and pandemics: prevention of harmful effects of tobacco, alcohol, and ultra-processed food and drink industries. Lancet. 2013;381(9867):670-9 https://doi.org/10.1016/S0140-6736(12)62089-3.

3. Freudenberg N. At what cost: modern capitalism and the future of health. USA: Oxford University Press; 2021.

4. McKee M, Stuckler D. Revisiting the corporate and commercial determinants of health. Am J Public Health. 2018;108(9):1167-70 https://doi.org/10.2105/A JPH.2018.304510. 
5. Smith JP. Markets, breastfeeding and trade in mothers' milk. Int Breastfeed J. 2015;10(1):1-7.

6. Jelliffe DB, Jelliffe EP. Human milk in the modern world. Oxford: Oxford University Press; 1978.

7. Uvnäs Moberg K, Ekström-Bergström A, Buckley S, Massarotti C, Pajalic Z, Luegmair $\mathrm{K}$, et al. Maternal plasma levels of oxytocin during breastfeeding - a systematic review. PLoS One. 2020;15(8):1-38.

8. Victora CG, Bahl R, Barros AJ, França GV, Horton S, Krasevec J, et al. Breastfeeding in the 21st century: epidemiology, mechanisms, and lifelong effect. Lancet. 2016;387(10017):475-90 https://doi.org/10.1016/S0140-673 6(15)01024-7.

9. Walters DD, Phan LT, Mathisen R. The cost of not breastfeeding: global results from a new tool. Health Policy Plan. 2019;34(6):407-17 https://doi. org/10.1093/heapol/czz050.

10. World Health Organization. Global Strategy for Infant and Young Child Feeding. Geneva; 2003. Available from: https://www.who.int/nutrition/ publications/infantfeeding/9241562218/en/

11. United Nations Children's Fund. Global UNICEF global databases: infant and young child feeding. New York; 2020. Available from: https://data.unicef.org/ topic/nutrition/infant-and-young-child-feeding/\#status

12. Neves PAR, Barros AJD, Baker P, Piwoz E, Santos TM, Gatica-Dominquez G, et al. Consumption of breast milk, formula and other non-human milk by children aged under two years: analysis of 86 low and middle-income countries. Public Health Nutr. 2020:1-20 https://doi.org/10.1017/S136898002 0004061.

13. Bergevin Y, Dougherty C, Kramer MS. Do infant formula samples shorten the duration of breast-feeding? Lancet. 1983;1 (8334):1148-51 https://doi. org/10.1016/s0140-6736(83)92878-7.

14. Sobel HL, lellamo A, Raya RR, Padilla AA, Olivé J-M, Nyunt-U S. Is unimpeded marketing for breast milk substitutes responsible for the decline in breastfeeding in the Philippines? An exploratory survey and focus group analysis. Soc Sci Med. 2011;73(10):1445-8 https://doi.org/10.1016/j. socscimed.2011.08.029.

15. Rosenberg KD, Eastham CA, Kasehagen LJ, Sandoval AP. Marketing infant formula through hospitals: the impact of commercial hospital discharge packs on breastfeeding. Am J Public Health. 2008;98(2):290-5 https://doi. org/10.2105/AJPH.2006.103218.

16. International Baby Food Action Network. Protecting Infant Health. A Health Workers Guide to the International Code of Marketing of Breast Milk Substitutes. 12th ed: IBFAN-ICDC; 2019.

17. World Health Organization, United Nations Children's Fund. Acceptable medical reasons for use of breast-milk substitutes. Geneva; 2009. Available from: https://apps.who.int/iris/bitstream/handle/10665/69938/WHO_FCH_CA H_09.01_eng.pdf?ua=1

18. World Health Organization. Maternal, infant and young child nutrition: Guidance on ending the inappropriate promotion of foods for infants and young children. Geneva; 2016. Available from: https:/apps.who.int/gb/ ebwha/pdf_files/WHA69/A69_7Add1-en.pdf?ua=1

19. Baker P, Machado P, Santos T, Sievert K, Backholer K, Hadjikakou M, et al. Ultra-processed foods and the nutrition transition: global, regional and national trends, food systems transformations and political economy drivers. Obes Rev. 2020;21(12):e13126 https://doi.org/10.1111/obr.13126.

20. Khandpur N, Neri DA, Monteiro C, Mazur A, Frelut ML, Boyland E, et al. Ultraprocessed food consumption among the Paediatric population: an overview and call to action from the European childhood obesity group. Ann Nutr Metab. 2020;76(2):109-13 https://doi.org/10.1159/000507840.

21. Coriolis. Understanding the infant formula value chain. Auckland; 2014 Available from: https://coriolisresearch.com/pdfs/coriolis_dairy_infant_ formula_value_chain.pdf

22. First Steps Nutrition Trust. Composition of infant milks and ingredients used. 2020. Available from: https://www.firststepsnutrition.org/compositioningredients-infant-milks. Accessed 5 Nov 2020

23. Palmer $\mathrm{G}$. The politics of breastfeeding: when breasts are bad for business: Pinter \& Martin Publishers; 2009.

24. Baker P, Smith J, Salmon L, Friel S, Kent G, lellamo A, et al. Global trends and patterns of commercial milk-based formula sales: is an unprecedented infant and young child feeding transition underway? Public Health Nutr. 2016;19(14):2540-50 https://doi.org/10.1017/S1368980016001117.

25. Food and Agricultural Organizaiton of the United Nations, World Health Organization. Enterobacter sakazakii and Salmonella in powdered infant formula. Meeting Report. Joint FAO/WHO Technical Meeting on
Enterobacter sakazakii and Salmonella Powdered Infant Formula. Rome; 2006. Available from: https://www.who.int/foodsafety/publications/mra10/en/

26. Li R, Magadia J, Fein SB, Grummer-Strawn LM. Risk of bottle-feeding for rapid weight gain during the first year of life. Arch Pediatrics Adolesc Med. 2012;166(5):431-6 https://doi.org/10.1001/archpediatrics.2011.1665.

27. Sokol EJ. The code handbook: a guide to implementing the international code of Marketing of Breastmilk Substitutes. Penang: International Baby Food Action Network, International Code Documentation Centre; 2005.

28. Chetley A. The politics of baby foods. Successful challenges to an international marketing strategy. London: Pinter; 1986.

29. Sikkink K. Codes of conduct for transnational corporations: the case of the WHO/UNICEF code. Int Organ. 1986;40(4):815-40 https://doi.org/10.1017/ S0020818300027387.

30. Braithwaite J, Drahos P. Global business regulation. Cambridge: Cambridge University Press; 2000. https://doi.org/10.1017/9780521780339

31. Richter J. Holding corporations accountable: corporate conduct, international codes, and citizen action: Palgrave Macmillan; 2001. https://doi. org/10.5040/9781350220607

32. World Health Organization. International Code of Marketing of Breast-milk Substitutes. Geneva; 1981. Available from: https:/www.who.int/nutrition/ publications/code_english.pdf

33. World Health Organization. Code and subsequent resolutions. Geneva; 2018. Available from: https:/www.who.int/nutrition/netcode/resolutions/en/

34. United Nations Office of the High Commissioner on the Rights of the Child. Convention on the Rights of the Child. Geneva; 1989. Available from: https://www.ohchr.org/en/professionalinterest/pages/crc.aspx

35. World Health Organization. Marketing of Breast-Milk Substitutes: National Implementation of the International Code Status Report. Geneva; 2020. Available from: https://www.who.int/publications/i/item/9789240006010

36. Baker P. Breastfeeding, first food systems and corporate power. Breastfeeding Review. 2020;28(2):33-7.

37. Baker P, Melo T, Augusto Neves P, Machado P, Smith J, Piwoz E, et al. Firstfood systems transformations and the ultra-processing of infant and young child diets: a synthesis of data and literature on the determinants, dynamics and consequences of the global rise in milk formula consumption. Maternal Child Nutr. 2020;17(2):1-18.

38. Euromonitor International. Passport global market information database. London; 2019

39. Save the Children. Don't Push It: Why the Formula Milk Industry Must Clean Up Its Act. London; 2013. Available from: https://resourcecentre.sa vethechildren.net/node/13218/pdf/dont-push-it.pdf

40. Choi Y, Ludwig A, Harris J. US toddler milk sales and associations with marketing practices. Public Health Nutr. 2019;23(6):1127-35.

41. Hastings G, Angus K, Eadie D, Hunt K. Selling second best: how infant formula marketing works. Glob Health. 2020;16(1):1-12.

42. Changing Markets Foundation. How milk formula companies are putting profits before science. Brussels, New York; 2017. Available from: https://cha ngingmarkets.org/portfolio/milking-it/

43. Tanrikulu H, Neri D, Robertson A, Mialon M. Corporate political activity of the baby food industry: the example of Nestlé in the United States of America. Int Breastfeed J. 2020;15:1-12.

44. Wagner-Rizvi T. The fox building the henhouse: corporate influence on global health governance and the risks to the World Health Organization. Ontario: University of Waterloo; 2020.

45. Granheim SI, Engelhardt K, Rundall P, Bialous S, lellamo A, Margetts B. Interference in public health policy: examples of how the baby food industry uses tobacco industry tactics. World Nutrition. 2017:8(2):288-310 https://doi.org/10.26596/wn.201782288-310.

46. Madureira Lima J, Galea S. Corporate practices and health: a framework and mechanisms. Globalization Health. 2018;14(21):1-12.

47. Fuchs D, Di Giulio A, Glaab K, Lorek S, Maniates M, Princen T, et al. Power: the missing element in sustainable consumption and absolute reductions research and action. J Clean Prod. 2016;132:298-307 https://doi.org/10.1016/ j.jclepro.2015.02.006.

48. Clapp J, Fuchs D. Agrifood corporations, global governance, and sustainability: a framework for analysis. In: Fuchs D, Clapp J, editors. Corporate power in global agrifood governance. Cambridge: MIT Press; 2009. p. 1-25. https://doi.org/10.7551/mitpress/9780262012751.003.0001.

49. Clapp J, Scrinis G. Big food, nutritionism, and corporate power. Globalizations. 2017;14(4):578-95 https://doi.org/10.1080/14747731.2016.123 9806 
50. Wilks S. The national identity of global companies. In: The handbook of global companies; 2013. p. 35-52. https://doi.org/10.1002/9781118326152. ch3.

51. Mikler J. The political power of global corporations. Cambridge: Wiley; 2018.

52. Sethi SP. Multinational corporations and the impact of public advocacy on corporate strategy: Nestle and the infant formula controversy: Springer Science \& Business Media; 2012.

53. Mialon M, Swinburn B, Sacks G. A proposed approach to systematically identify and monitor the corporate political activity of the food industry with respect to public health using publicly available information. Obes Rev. 2015;16(7):519-30 https://doi.org/10.1111/obr.12289.

54. Fuchs D. Exploring the role of business in global governance. Business power in global governance. Boulder, Colorado: Lynne Rienner; 2007.

55. Fuchs D. Theorizing the power of global companies. In: The handbook of global companies. West Sussex: Wiley; 2013. p. 77-95. https://doi.org/10.1 002/9781118326152.ch5

56. McDonough T, Reich M, Kotz D. Introduction: social structure of accumulation theory for the 21 st century. In: Kotz D, Reich M, McDonough T, editors. Contemporary capitalism and its crises: social structure of accumulation theory for the 21 st century. Cambridge: Cambridge University Press; 2010. https://doi.org/10.1017/CBO9780511804335.001

57. Sammut-Bonnici T, Galea D. PEST analysis. In: Cooper C, editor. Wiley encyclopedia of management. New Jersey: Wiley; 2014.

58. Milsom P, Smith R, Baker P, Walls H. Corporate power and the international trade regime preventing progressive policy action on non-communicable diseases: a realist review. Health Policy Plan. 2020; https://doi.org/10.1093/ heapol/czaa148.

59. Keck ME, Sikkink K. Activists beyond borders: advocacy networks in international politics: Cornell University Press; 2014. https://doi.org/10.7591/ 9780801471292

60. Gaventa J. Finding the Spaces for Change: A Power Analysis. Institute of Development Studies Bulletin. 2006:37(6):23-33.

61. Compustat Industrial. New York: Standard \& Poor's; 2020.

62. Fortune Media Group Holdings. Fortune 500; 2018. Available from: https:// fortune.com/fortune500/.

63. Forbes Media. Global 2000 The World's largest public companies. Jersey City. Available from: https://www.forbes.com/global2000/\#7863c977335d

64. United Nations. UN Comtrade international trade statistics database; 2017 Available from: https://comtrade.un.org/.

65. Food and Agricultural Organizaiton of the United Nations. FAOSTAT; 2017. Available from: http://www.fao.org/faostat/en/.

66. Codex Alimentarius Commission. Codex Committee on Nutrition and Foods for Special Dietary Uses (CCNFSDU). Rome; 2019. Available from: http:// www.fao.org/fao-who-codexalimentarius/committees/committee/relatedmeetings/en/?committee=CCNFSDU

67. Centre for Responsive Politics. OpenSecrets.org. Washington, D.C.; 2020. Available from: https://www.OpenSecrets.org/federal-lobbying/.

68. Corbin J, Strauss A. Basics of qualitative research: techniques and procedures for developing grounded theory: sage publications; 2014

69. Nestle S.A. Annual Review 2018. Vevey; 2018

70. Apple RD. Mothers and medicine: a social history of infant feeding, 18901950. Madison: University of Wisconsin Press; 1987.

71. Stevens EE, Patrick TE, Pickler R. A history of infant feeding. J Perinat Educ. 2009;18(2):32-9 https://doi.org/10.1624/105812409X426314.

72. Apple RD. "Advertised by our loving friends": the infant formula industry and the creation of new pharmaceutical markets, 1870-1910. J Hist Med Allied Sci. 1986:41(1):3-23 https://doi.org/10.1093/jhmas/41.1.3.

73. Pfiffner A. Henri Nestlé: From Pharmacist's Assistant to Founder of the World's Largest Food Company; 1814-1890. Cham and Vevey; Nestlé; 2014. Available from: https://www.nestle.com/sites/default/files/asset-library/ documents/about_us/henri-nestle-biography-en.pdf.

74. Wilhelm L. 'One of the Most urgent problems to solve': malnutrition, transImperial nutrition science, and Nestlé's medical pursuits in late colonial Africa. J Imperial Commonwealth History. 2020:48(5):914-33 https://doi. org/10.1080/03086534.2020.1816624.

75. Koese Y. Nestlé in the ottoman empire: global marketing with local flavor. Enterprise Society. 1870-1927;2008:724-61.

76. Fazwal A, Holla R. The Boycott Book. online; Self-published; 2019. Available from: http://www.theboycottbook.com/intro.pdf

77. Fomon SJ. Infant feeding in the 20th century: formula and beikost. J Nutr. 2001;131(2):409S-20S https://doi.org/10.1093/jn/131.2.409S.
78. Post J. Assessing the Nestle Boycott: Corporate Accountability and Human Rights. California Manag Review. 1985; XXVII(2):113-131.

79. Popkin BM, Fernandez ME, Avila JL. Infant formula promotion and the health sector in the Philippines. Am J Public Health. 1990;80(1):74-5 https:// doi.org/10.2105/AJPH.80.1.74.

80. World Health Organization. Information concerning the use and marketing of follow-up formula. Geneva; 2013. Available from: http://www.who.int/ nutrition/topics/WHO_brief_fufandcode_post_17July.pdf

81. Labonté R, Stuckler D. The rise of neoliberalism: how bad economics imperils health and what to do about it. J Epidemiol Community Health. 2016;70(3):312-8 https://doi.org/10.1136/jech-2015-206295.

82. Rushton S, Williams OD. Frames, paradigms and power: global health policy-making under neoliberalism. Glob Soc. 2012;26(2):147-67 https://doi. org/10.1080/13600826.2012.656266

83. Burch D, Lawrence $G$. Towards a third food regime: behind the transformation. Agric Hum Values. 2009;26(4):267-79 https://doi.org/10.1 007/s10460-009-9219-4.

84. Hawkes $C$. The role of foreign direct investment in the nutrition transition. Public Health Nutr. 2005;8(4):357-65 https://doi.org/10.1079/PHN2004706.

85. Baker P, Kay A, Walls H. Trade and investment liberalization and Asia's noncommunicable disease epidemic - a synthesis of data and existing literature. Globalization and Health. 2014;10(66):1-20.

86. Hawkes C. Uneven dietary development: linking the policies and processes of globalization with the nutrition transition, obesity and diet-related chronic diseases. Glob Health. 2006;2(1):4 https://doi.org/10.1186/17448603-2-4

87. UNCTAD. Chapter II The shifting contours of trade under hyperglobalization. In: Trade and development report 2018: power, platforms and the free trade delusion. Geneva: UNCTAD; 2018. Available from: https://unctad.org/system/ files/official-document/tdr2018ch2 en.pdf

88. Euromonitor International. Abbott Laboratories Inc in packaged food (World). London; 2016

89. Clay N, Garnett T, Lorimer J. Dairy intensification: drivers, impacts and alternatives. Ambio. 2019:1-14

90. Foote KJ, Joy MK, Death RG. New Zealand dairy farming: milking our environment for all its worth. Environ Manag. 2015;56(3):709-20 https://doi. org/10.1007/s00267-015-0517-x.

91. Galtry JA. Improving the New Zealand dairy industry's contribution to local and global wellbeing: the case of infant formula exports. New Zealand Med J. 2013;126(1386):82-9.

92. Gao HS. China-New Zealand free trade agreement; 2016. Available from: https://www.researchgate.net/publication/325596069_China-New_Zealand_ free_trade_agreement

93. Global M\&A Partners. Food Ingredients Sector. Dublin; 2018. Available from: http://acquizon.com/wp-content/uploads/2019/05/GMAP-Food-IngredientsSector-Report-2018.pdf

94. Lee R. Ethics and politics of breastfeeding: power. Pleasure, Poetics: University of Toronto Press; 2018. https://doi.org/10.3138/9781487518561

95. Friesland Campina. Trade associations and memberships. 2020. Available from: https://www.frieslandcampina.com/uploads/2020/06/FrieslandCampina-Tra de-Associations-and-Partnerships-2020-v2.pdf. Accessed 11 Aug 2020

96. Wagner-Rizvi T. Regulating baby food marketing: civil society versus private sector influence. In: Kenworthy N, MacKenzie R, editors. Case studies on corporations and global health governance: impacts, influence and accountability. Lanham: Rowman \& Littlefield; 2016.

97. World Health Organization. Report of the standing committee on nongovernmental organizations. Geneva; 1987.

98. Gerber J. Enforced Self-Regulation in the Infant Formula Industry: A Radical Extension of an" Impractical" Proposal. Social Justice. 1990;17((1(39))):98-112.

99. International Special Dietary Food Industries. About us. 2018. Available from: https://www.isdi.org/about/. Accessed 12 July 2020

100. European Foundation for the Care of Newborn Infants. For the best start in life. 2020. Available from: https://www.efcni.org/. Accessed 8 Apr 2021

101. Yamey G. Baby food industry lobbies WHO on breast feeding advice. 2000; 321(7261):591

102. Nebehay S. WHO guidance on infant milk formulas gets lukewarm backing. 2016. Available from: https://fr.reuters.com/article/us-health-who-milkidUSKCNOYI24J. Accessed 20 June 2020

103. Jacobs A. U.S. Opposition to breast-feeding resolution stuns world health officials. 2018. Available from: https://www.nytimes.com/2018/07/08/health/ worldhealth-breastfeeding-ecuador-trump.html. Accessed July 82020 
104. World Health Organization. Safeguarding against possible conflicts of interest in nutrition programmes: Approach for the prevention and management of conflicts of interest in the policy development and implementation of nutrition programmes at country level. Geneva; 2017. Available from: https://www.who.int/nutrition/consultation-doi/comments/ en/

105. Arendt M. Codex Alimentarius: what has it to do with me? J Hum Lact. 2018:34(4):704-10 https://doi.org/10.1177/0890334418794658.

106. Koletzko B, Shamir R. Editorial: standards for infant formula milk: commercial interests may be the strongest driver of what goes into formula milk. $\mathrm{Br}$ Med J. 2006;16(332):621.

107. Thow AM, Jones A, Schneider CH, Labonté R. Global governance of front-ofpack nutrition labelling: a qualitative analysis. Nutrients. 2019;11(2):268 https://doi.org/10.3390/nu11020268.

108. World Health Organization, United Nations Children's Fund. International trade agreements and implementation of the International Code of Marketing of Breast-milk Substitutes: frequently asked questions. Geneva; 2020. Available from: https://www.who.int/publications/i/item/9789240002 739

109. Greene JL. Dairy Provisions in USMCA. Washington D.C: United States Government Congressional Research Service; 2019. Available from: https://fa s.org/sgp/crs/row/IF11149.pdf

110. Keller and Heckman LLP. China Passes Sweeping Amendment to Food Safety Law: The Most Stringent To Date: Lexis Nexis; 2015. Available from: https://www.lexisnexis.com/legalnewsroom/public-policy/b/public-policy-la w-blog/posts/china-passes-sweeping-amendment-to-food-safety-law-themost-stringent-to-date

111. Liu Z, Mutukumira AN, Chen H. Food safety governance in China: from supervision to coregulation. Food Sci Nutr. 2019;7(12):4127-39 https://doi. org/10.1002/fsn3.1281

112. Office of the United States Trade Representative. 2020 National Trade Estimate Report on Foreign Trade Barriers. Washington D.C; 2020. Available from: https://ustr.gov/sites/default/files/2020_National_Trade_Estimate_ Report.pdf

113. Corporate Crime Reporter. Gerber uses threat of GATT sanctions to gain exemption from Guatemalan infant health law. 1996;10(14).

114. Astley M. Infant formula manufacturers opposing proposed Hong Kong promotion ban. 2012. Available from: https://www.dairyreporter.com/A rticle/2012/11/20/Infant-formula-manufacturers-opposing-proposed-HongKong-promotion-ban. Accessed 18 Nov 2020

115. Kogan LA. Hong Kong's Draft Infant Formula \& Complementary Foods Marketing Code Violates WTO law; LexisNexis legal newsroom international law; 2014. Available from: https://papers.ssrn.com/sol3/papers.cfm?abstract_ $\mathrm{id}=\% 202411187$.

116. Office of the United States Trade Representative. 2017 National Trade Estimate Report on Foreign Trade Barriers. Washington D.C; 2017. Available from: https://ustr.gov/sites/default/files/files/reports/2017/NTE/2017\%20NTE. pdf

117. Doucet K. India's infant Milk substitutes act, monitoring, and enforcement. New Haven: Yale School of Medicine; 2018. Available from: https://medicine. yale.edu/news-article/17463/

118. Office of the United States Trade Representative. 2009 National Trade Estimate Report on Foreign Trade Barriers. Washington D.C; 2009. Available from: https://ustr.gov/archive/assets/Document_Library/Reports_Publica tions/2009/2009_National_Trade_Estimate_Report_on_Foreign_Trade_Ba rriers/asset_upload_file405_15451.pdf

119. Office of the United States Trade Representative. 2018 National Trade Estimate Report on Foreign Trade Barriers. Washington D.C; 2018. Available from: https://ustr.gov/sites/default/files/files/Press/Reports/2018\%20Nationa 1\%20Trade\%20Estimate\%20Report.pdf

120. Save the Children. Superfood for babies: how overcoming barriers to breastfeeding will save children's lives. London; 2013. Available from: https://resourcecentre.savethechildren.net/node/7151/pdf/7151.pdf

121. Sharfstein JM, Silver DL. Relationship between the American academy of pediatrics and infant formula companies. JAMA Pediatr. 2017;171(7):613-4 https://doi.org/10.1001/jamapediatrics.2017.1257.

122. Nestle M. Food politics: how the food industry influences nutrition and health: Univ of California press; 2013.

123. Pierangelo CA. Dear Chairman Nguyen Sinh Hung. Hanoi: Embassy of the United States of America Hanoi; 2012. Available from: http://www.infactcana da.ca/pdf/vietnam-us-embassy-letter.pdf
124. Kent G. WIC's promotion of infant formula in the United States. Int Breastfeed J. 2006;1(1):8 https://doi.org/10.1186/1746-4358-1-8.

125. Kent G. Conflicts of interest in the WIC program. World Nutrition. 2017;8(1): 128-43 https://doi.org/10.26596/wn.201781128-143.

126. Abbott Laboratories. Corporate political participation; 2020. Available from: https://www.abbott.com/investors/governance/corporate-political-participa tion.html.

127. International Association of Infant Food Manufacturers. Infant Food Manufacturers' Commitment and Rules for Responsible Conduct 2014 Available from: https://www.meadjohnson.com/sites/corp/files/IFM_Rules-ofResponsible-Conduct.pdf.

128. Nestle SA. The Nestlé policy and procedures for the implementation of the WHO international code of Marketing of Breast Milk Substitutes. Vevey; 2017. Available from: https://www.nestle.com/sites/default/files/asset-library/ documents/creating\%20shared\%20value/nutrition/nestle_policy_who_ code_en.pdf

129. Access to Nutrition Initiative. BMS Marketing Report Global Index 2018. Utrecht; 2018. Available from: https://accesstonutrition.org/index/globalindex-2018/bms-marketing/

130. International Baby Food Action Network and International Code Documentation Centre. Breaking the Rules 2017: Evidence of Violations of the International Code of Marketing of Breastmilk Substitutes and Subsequent Resolutions. Penang; 2017.

131. Zehner E, Champeny M, Huffman SL. Marketing and infant and young child feeding in rapidly evolving food environments. Maternal Child Nutr. 2019; 15(S4):e12810.

132. UNICEF UK, National Childbirth Trust, Save the Children UK. A weak formula for legislation: how loopholes in the law are putting babies at risk. London; 2007. Available from: https://resourcecentre.savethechildren.net/node/134 03/pdf/babymilk_legislation_1.pdf

133. Reckitt Benckiser Group plc. The International Baby Food Action Network (IBFAN) 'Breaking the Rules, Stretching the Rules - 2017' Response and Action Plan. Slough; 2018. Available from: https://www.rb.com/media/3482/ response-to-ibfan-report-20-june-2018.pdf

134. Lubbers E. Secret Manoeuvres in the dark: London: Pluto press; 2012.

135. FTSE Russell. Providing context to the FTSE4Good BMS verification process. London; 2015. Available from: https://research.ftserussell.com/products/ downloads/Providing-Context-to-the-FTSE4Good-BMS-Verification-Process. pdf

136. Nestle SA. Nestlé's comments on the verification report of the 2017 FTSE4Good breast Milk substitutes marketing assessment. Vevey; 2017 Available from: https://research.ftserussell.com/products/downloads/nestleresponse-f4g-bms-2017.pdf

137. Nestle S.A. Press release: Nestlé tops 2018 Access to Nutrition Index 2018. Available from: https://www.nestle.com/media/pressreleases/allpressrelea ses/nestle-tops-2018-access-to-nutrition-index. Accessed 15 Sept 2020

138. Confino J. Nestlé chairman warns against playing god over climate change. 2014. Available from: https://www.theguardian.com/sustainable-business/ blog/nestle-chairman-climate-change-controversy-peter-brabeck. Accessed 14 Dec 2020

139. Food and Agricultural Organizaiton of the United Nations. FAO and Danone team up to foster sustainable diets and food systems. Rome; 2019. Available from: http://www.fao.org/news/story/en/item/1237744/icode/

140. Abbott Laboratories. Abbott Fund. 2020. Available from: https://www.a bbott.com/responsibility/abbott-fund.html. Accessed 17 Sept 2020

141. Danone Ecosystem Fund. Women Empowerment: Women Empowerment for Inclusive Business - Learnings from Ecosystem Projects and Partnerships. Paris: Danone; 2016. Available from: https://www.danone.com/content/dam/ danone-corp/danone-com/about-us-impact/policies-and-commitments/ en/2016/2016_04_21_WomenEmpowermentBooklet.pdf

142. Carothers C, Gribble K. Infant and young child feeding in emergencies. J Hum Lact. 2014;30(3):272-5 https://doi.org/10.1177/0890334414537118.

143. Mead Johnson Nutrition. Mead Johnson Disaster Relief Overview - A Record-Setting Month. 2017. Available from: https://www.meadjohnson. com/journal/mead-johnson-disaster-relief-overview-\%E2\%80\%93-recordsetting-month. Accessed 17 Sept 2020

144. Ching C, Zambrano P, Nguyen TT, Tharaney M, Zafimanjaka MG, Mathisen R. Old tricks, new opportunities: how companies violate the international code of Marketing of Breast-Milk Substitutes and Undermine Maternal and child health during the COVID-19 pandemic. Int J Environ Res Public Health. 2021;18(5):2381 https://doi.org/10.3390/ijerph18052381. 
145. Rundall P. How companies exploit the COVID-19 crisis. 2020. Available from: http://www.babymilkaction.org/archives/24341. Accessed 30 Mar 2021

146. Piwoz EG, Huffman SL. The impact of marketing of breast-milk substitutes on WHO-recommended breastfeeding practices. Food Nutr Bull. 2015;36(4): 373-86 https://doi.org/10.1177/0379572115602174.

147. Rose A. Danone to name new management at China unit after bribery scandal. Reuters. 2013; Available from: https://www.reuters.com/article/ukchina-danone-bribery/danone-to-name-new-management-at-china-unit-a fter-bribery-scandal-idUKBRE99E01Y20131015. Accessed Oct 202020.

148. Nestle Nutrition Institute. Inspired by Human Milk Research. Vevey; 2019. Available from: https://www.nestlenutrition-institute.org/docs/defaultsource/global-dcoument-library/publications/secured/inspired-by-humanmilk-research-abstracts\%2D\%2D-espghan-2019-(2).pdf?sfvrsn=a41b20ed_2

149. Nestle Nutrition Institute. About Us. 2020. Available from: https://www. nestlenutrition-institute.org/about-us. Accessed 17 Sept 2020

150. Abbott Laboratories. Advancing clinical nutrition in China and Vietnam. 2018. Available from: https://www.abbott.com/responsibility/social-impact/a ccess-to-healthcare/articles/partnering-across-asia.html. Accessed 16 Sept 2020

151. Gummer-Strawn L, Holliday F, Tabea Jungo K, Rollins N. Sponsorship of national and regional professional paediatrics associations by companies that make breast-milk substitutes: evidence from a review of official websites. BMJ Open. 2019;9:1-6.

152. Seals Allers K. Does the A.A.P. Logo Belong on Formula Gift Bags? 2013. Available from: https://parenting.blogs.nytimes.com/2013/12/19/doesthe-a-a-p-logo-belong-on-formula-gift-bags/. Accessed 15 Oct 2020

153. van Tulleken C. Overdiagnosis and industry influence: how cow's milk protein allergy is extending the reach of infant formula manufacturers. $\mathrm{Br}$ Med J. 2018;363.

154. Martin CR, Ling P-R, Blackburn GL. Review of infant feeding: key features of breast milk and infant formula. Nutrients. 2016;8(5):279 https://doi.org/10.33 90/nu8050279.

155. Kerzner B, Milano K, MacLean WC, Berall G, Stuart S, Chatoor I. A practical approach to classifying and managing feeding difficulties. Pediatrics. 2015; 135(2):344-53 https://doi.org/10.1542/peds.2014-1630.

156. Garg P, Williams JA, Satyavrat V. A pilot study to assess the utility and perceived effectiveness of a tool for diagnosing feeding difficulties in children. Asia Pac Fam Med. 2015;14(1):7 https://doi.org/10.1186/s12930-01 5-0024-5.

157. Mak VS. How picky eating becomes an illness-marketing nutrient-enriched formula Milk in a Chinese society. Ecol Food Nutr. 2017;56(1):81-100 https:// doi.org/10.1080/03670244.2016.1261025.

158. McGarity TO, Wagner WE. Bending science: how special interests corrupt public health research. Cambridge: Harvard University Press; 2010. https:// doi.org/10.2307/j.ctv13qftkm

159. Nestle M. Unsavory truth: how food companies skew the science of what we eat. New York: Basic Books; 2018.

160. Green H. Global obesity: Nestlé initiatives in nutrition, health, and wellness. Nutrition Reviews. 2006;64(suppl_1):S62-S4.

161. Nestle S.A. Welcome to the research center. 2020. Available from: https:// www.nestlenutrition-institute.org/research-center. Accessed 24 Aug 2020

162. Scrinis G. Nutritionism: the science and politics of dietary advice. New York: Columbia University Press; 2013. https://doi.org/10.7312/scri15656

163. Berry NJ, Gribble KD. Health and nutrition content claims on websites advertising infant formula available in Australia: a content analysis. Maternal Child Nutr. 2017;13(4):e12383.

164. Harris J, Fleming-Milici F, Frazier W, Haraghey K, Kalnova S, Romo-Palafox M, et al. Baby food FACTS: Nutrition and marketing of baby and toddler food and drinks. 2017 Accessed. Available from: http://www.uconnruddcenter. org/files/Pdfs/BabyFoodFACTS_FINAL.pdf.

165. Romo-Palafox MJ, Pomeranz JL, Harris JL. Infant formula and toddler milk marketing and caregiver's provision to young children. Maternal Child Nutr. 2020:e12962.

166. Berry NJ, Jones S, Iverson D. It's all formula to me: women's understandings of toddler milk ads. Breastfeeding Review. 2010;18(1):21-30.

167. Friesland Campina Institute for Diary NaH. FrieslandCampina Institute at a glance: About dairy, nutrition and health. Amersfoot; 2017. Available from: https://www.frieslandcampinainstitute.com/uploads/sites/2/2018/05/FCInstitute-Brochure-At-a-glance-July-2017.pdf

168. Eldridge AL. FITS and KNHS overview: Methodological challenges in dietary intake data collection among infants, toddlers, and children in selected countries: Nestle Nutrition Institute; 2019. Available from: https://www nestlenutrition-institute.org/resources/publication-series/publications/article/ details/nniw91\%2D\%2D-nurturing-a-healthy-generation-of-children-researchgaps-and-opportunities/fits-and-knhs-overview-methodological-challengesin-dietary-intake-data-collection-among-infants-toddlers-and-children-inselected-countries

169. Nestle Nutrition Institute. Nurturing a Healthy Generation of Children: Research Gaps and Opportunities. Vevey; 2019. Available from: https://www. nestlenutrition-institute.org/docs/default-source/global-dcoument-library/ publications/secured/nniw91-booklet\%2D\%2D-nurturing-a-healthy-generationof-children\%2D\%2D-research-gaps-and-opportunities.pdf?sfvrsn=8c114ced_0

170. Steele S, Ruskin G, Stuckler D. Pushing partnerships: corporate influence on research and policy via the international Life Sciences Institute. Public Health Nutr. 2020:1-9.

171. lacobucci G. Food and soft drink industry has too much influence over US dietary guidelines, report says. Br Med J. 2020;369:m1666.

172. Williams SN. The incursion of 'big Food'in middle-income countries: a qualitative documentary case study analysis of the soft drinks industry in China and India. Crit Public Health. 2015;25(4):455-73 https://doi.org/10.1 080/09581596.2015.1005056

173. Greenhalgh S. Soda industry influence on obesity science and policy in China. J Public Health Policy. 2019;40(1):5-16 https://doi.org/10.1057/s41271018-00158-x.

174. International Life Science Institute. Maternal and child nutrition improvement in Southeast Asia region: a success Story from the Southeast Asia region; 2020. Available from: https://ilsi.org/science-research/maternal-a nd-child-nutrition-improvement-in-southeast-asia-region/.

175. China Development Research Foundation. Investigative report on factors affecting breastfeeding in China. Beijing; 2019. Available from: https://cdrf. org.cn/jjh/pdf/mu.pdf

176. Johnson B. World's largest advertisers 2017. Advertising Age. 2017;88(23):9

177. Abrahams SW. Milk and social media: online communities and the international code of Marketing of Breast-milk Substitutes. J Hum Lact. 2012 28(3):400-6 https://doi.org/10.1177/0890334412447080.

178. Zhao J, Li M, Freeman B. A baby formula designed for Chinese babies: content analysis of Milk formula advertisements on Chinese parenting apps. JMIR Mhealth Uhealth. 2019;7(11):e14219 https://doi.org/10.2196/14219.

179. Furneaux R. The baby brands turning Indonesian Instagram into free formula ads. 2020. Available from: https://www.thebureauinvestigates.com/ stories/2020-07-30/the-baby-brands-turning-indonesian-instagram-into-freeformula-milk-ads. Accessed 9 Dec 2020

180. Bhatt N. Breastfeeding in India is disrupted as mothers and babies are separated in the pandemic. Br Med J. 2020;370:m3316.

181. Pereira-Kotze C, Doherty T, Swart EC. Use of social media platforms by manufacturers to market breast-milk substitutes in South Africa. BMJ Glob Health. 2020;5(12):e003574 https://doi.org/10.1136/bmjgh-2020-003574.

182. Montgomery K, Chester J, Nixon L, Levy L, Dorfman L. Big data and the transformation of food and beverage marketing: undermining efforts to reduce obesity? Crit Public Health. 2019;29(1):110-7 https://doi.org/10.1080/ 09581596.2017.1392483.

183. Mejia P, Seklir L, Gardin K, Nixon L. Mother and child promotion: a preliminary analysis of social media marketing of infant formula. Berkeley: Berkeley Media Studies Group; 2016.

184. Pereira C, Ford R, Feeley A. Cross-sectional survey shows that follow-up formula and growing-up milks are labelled similarly to infant formula in four low and middle income countries. Maternal Child Nutr. 2016;12:91-105.

185. Hughes HK, Landa MM, Sharfstein JM. Marketing claims for infant formula: the need for evidence. JAMA Pediatr. 2017;171(2):105-6 https://doi.org/10.1 001/jamapediatrics.2016.3837.

186. First Steps Nutrition Trust. Claims made for infant formula, ingredients and formulations. London; 2020. Available from: https://static1.squarespace.com/ static/59f75004f09ca48694070f3b/t/5eba3eac6a3b687667d9891e/158926404 6551/Claims_made_for_infant_formula_and_ingredients_May2020_final.pdf

187. First Steps Nutrition Trust. Scientific and factual? A further review of breastmilk substitute advertising to healthcare professionals. London; 2020. Available from: https://static1.squarespace.com/static/59f75004f09ca48694 070f3b/t/5d00a07858660d0001500ca0/1560322176680/Scientific_and_Fa ctual_booklet_June_2019_for_web.pdf

188. Belamarich PF, Bochner RE, Racine AD. A critical review of the marketing claims of infant formula products in the United States. Clin Pediatr. 2016: 55(5):437-42 https://doi.org/10.1177/0009922815589913. 
189. Stang J, Hoss K, Story M. Health statements made in infant formula advertisements in pregnancy and early parenting magazines: a content analysis. Infant Child Adolesc Nutr. 2010;2(1):16-25.

190. Baker P, Hawkes C, Wingrove K, Demaio AR, Parkhurst J, Thow AM, et al. What drives political commitment for nutrition? A review and framework synthesis to inform the United Nations Decade of Action on Nutrition. BMJ Global Health. 2018;3(1):1-14.

191. Harris JL, Pomeranz JL. Infant formula and toddler milk marketing: opportunities to address harmful practices and improve young children's diets. Nutr Rev. 2020;78(10):866-83 https://doi.org/10.1093/nutrit/nuz095.

192. Dykes $F$. The education of health practitioners supporting breastfeeding women: time for critical reflection. Maternal Child Nutr. 2006;2(4):204-16 https://doi.org/10.1111/j.1740-8709.2006.00071.x

193. Gavine A, MacGillivray S, Renfrew MJ, Siebelt L, Haggi H, McFadden A. Education and training of healthcare staff in the knowledge, attitudes and skills needed to work effectively with breastfeeding women: a systematic review. Int Breastfeed J. 2017;12(1):6.

194. World Health Organization. National Implementation of the Baby-friendly Hospital Initiative 2017. Geneva; 2017. Available from: http://apps.who.int/ gb/ebwha/pdf_files/WHA69/A69_7Add1-en.pdf?ua=1

195. UN General Assembly. Convention on the Rights of the Child - General comment No. 25 (2021) on children's rights in relation to the digital environment. New York; 2021. Available from: https://docstore.ohchr.org/ SelfServices/FilesHandler.ashx?enc=6QkG1 d\%2fPPRiCAahKb7yhsqlkirKQZLK2 M58RF\%2f5F0vEG\%2bcAAx34gC78FwvnmZXGFUI9nJBDpKR1dfKekJxW2 w70\%2b3nRpHZVnUfEOn49xulgBmsRD7nyWwxR\%2fYnlpnMdh

196. Fooks GJ, Gilmore AB, Smith KE, Collin J, Holden C, Lee K. Corporate social responsibility and access to policy élites: an analysis of tobacco industry documents. PLoS Med. 2011;8(8):e1001076 https://doi.org/10.1371/journal. pmed.1001076.

197. Miller D, Harkins C. Corporate strategy, corporate capture: food and alcohol industry lobbying and public health. Crit Soc Policy. 2010;30(4):564-89 https://doi.org/10.1177/0261018310376805.

198. McCambridge J, Mialon M, Hawkins B. Alcohol industry involvement in policymaking: a systematic review. Addiction. 2018;113(9):1571-84 https:// doi.org/10.1111/add.14216

199. Holden C, Lee K. Corporate power and social policy: the political economy of the transnational tobacco companies. Global Soc Policy. 2009;9(3):328-54 https://doi.org/10.1177/1468018109343638.

200. Fuchs D. Commanding heights? The strength and fragility of business power in global politics. Millennium. 2005;33(3):771-801 https://doi.org/1 $0.1177 / 03058298050330030501$.

201. Clift J, Thacher E, D'Alimonte M. Funding breastfeeding promotion in developing countries. 2018. Available from: https://r4d.org/blog/fundingbreastfeeding-promotion-in-developing-countries-how-much-does-theunited-states-contribute/. Accessed 8 Apr 2021

202. Millar J. The corporate determinants of health: how big business affects our health, and the need for government action! Can J Public Health. 2013; 104(4):327-9.

203. XinhuaNet. China to stay over $60 \mathrm{pct}$ self-sufficient in baby formula production. 2019. Available from: http://www.xinhuanet.com/english/201 9-11/19/c_138565671_2.htm. Accessed 8 Sept 2020

204. Munblit D, Perkin MR, Palmer DJ, Allen KJ, Boyle RJ. Assessment of evidence about common infant symptoms and Cow's Milk allergy. JAMA Pediatr. 2020;174(6):599-608 https://doi.org/10.1001/jamapediatrics.2020.0153.

205. Clapp J. Financialization, distance and global food politics. J Peasant Stud. 2014;41(5):797-814 https://doi.org/10.1080/03066150.2013.875536.

206. Karlsson JO, Garnett T, Rollins NC, Röös E. The carbon footprint of breastmilk substitutes in comparison with breastfeeding. J Clean Prod. 2019;222:436-45 https://doi.org/10.1016/j.jclepro.2019.03.043.

\section{Publisher's Note}

Springer Nature remains neutral with regard to jurisdictional claims in published maps and institutional affiliations.

Ready to submit your research? Choose BMC and benefit from:

- fast, convenient online submission

- thorough peer review by experienced researchers in your field

- rapid publication on acceptance

- support for research data, including large and complex data types

- gold Open Access which fosters wider collaboration and increased citations

- maximum visibility for your research: over $100 \mathrm{M}$ website views per year

At BMC, research is always in progress.

Learn more biomedcentral.com/submissions 